\title{
Re-assessment of phosphorus availability in fens with varying contents of iron and calcium
}

\author{
A. M. Kooijman • C. Cusell • L. Hedenäs • \\ L. P. M. Lamers • I. S. Mettrop • T. Neijmeijer
}

Received: 11 April 2019/Accepted: 29 July 2019/Published online: 5 December 2019

(C) The Author(s) 2019

\begin{abstract}
Aim To further unravel $\mathrm{P}$ availability in mineral-rich fens, and test whether high Fe in the soil would lead to low $\mathrm{P}$ availability to the vegetation.

Methods Mesotrophic fens were selected over gradients in $\mathrm{Ca}$ and $\mathrm{Fe}$ in central Sweden and the Netherlands, to study characteristics of vegetation, pore water and peat soil, including inorganic and organic forms of $\mathrm{P}, \mathrm{Fe}$ and Al.

Results Soil Fe was more important than region or soil $\mathrm{Ca}$, and $\mathrm{P}$ availability to the vegetation increased from

\footnotetext{
Highlights

- This study provides further evidence that F-rich fens are not Ppoor but P-rich

- Fe-rich fens have high total $\mathrm{P}$, but especially a lot of weakly sorbed $\mathrm{P}_{\mathrm{i}}$ and $\mathrm{P}_{\mathrm{o}}$

- High $\mathrm{P}$ in Fe-rich fens does not lead to high biomass, but may reduce Fe-toxicity

- Ca-rich fens are P-poor, mainly due to low Fe and low P-sorption capacity
}

Responsible Editor: N. Jim Barrow.

\author{
A. M. Kooijman $(\bowtie) \cdot$ C. Cusell $\cdot$ I. S. Mettrop • \\ T. Neijmeijer \\ Department of Ecosystem and Landscape Dynamics, Institute for \\ Biodiversity and Ecosystem Dynamics (IBED), University of \\ Amsterdam, P.O. Box 94240, NL-1090 GEAmsterdam, \\ The Netherlands \\ e-mail: a.m.kooijman@uva.nl \\ C. Cusell · L. P. M. Lamers • I. S. Mettrop \\ Department of Aquatic Ecology \& Environmental Biology, \\ Institute for Water and Wetland Research, Radboud University \\ Nijmegen, NL-6525 AJNijmegen, The Netherlands
}

Fe-poor to Fe-rich fens. Contrary to expectations, precipitation of iron phosphates played a minor role in $\mathrm{Fe}-$ rich fens. Fe-rich fens were P-rich for three reasons: (1) high P sorption capacity, (2) relatively weak sorption to Fe-OM complexes and (3) high amounts of sorbed organic P, which probably consists of labile P. Also, nonmycorrhizal wetland plants probably especially take up weakly sorbed (organic) P. However, high P did not lead to high biomass or low plant diversity. Fe-rich fens were limited by other nutrients, and high $\mathrm{P}$ may help protect the vegetation against Fe-toxicity.

\author{
C. Cusell \\ Witteveen+Bos, NL-7400 AEDeventer, The Netherlands \\ L. Hedenäs \\ Department of Botany, Swedish Museum of Natural History, Box \\ 50007, 10405 Stockholm, Sweden

\section{S. Mettrop} \\ Altenburg and Wymenga Ecological Consultants, Suderwei 2, \\ 9269 TZVeenwouden, The Netherlands
}


Conclusions Fe-poor fens are P-poor, irrespective of $\mathrm{Ca}$, and Fe-rich fens P-rich even under mesotrophic conditions. However, high $\mathrm{P}$ itself does not endanger Fe-rich fens.

Keywords Mineral-rich fens · Plant diversity · Nutrients · Humic Fe-Al complexes · Central Sweden . The Netherlands

\section{Introduction}

Mineral-rich fens are important habitats for biodiversity. They are rich in spectacular and strictly restricted plant species (European Union 2013), and home to the EUhabitat directive species such as Hamatocaulis vernicosus and Liparis loeselii. Mineral-rich fens belong to protected EU-habitat types such as Transition mires (H7140), Alkaline fens (H7230) and Molinia meadows on calcareous, peaty or clayey-silt laden soil (H6410), but they have undergone a serious decline in Europe. Apart from habitat destruction and drainage, mineral-rich fens are threatened by eutrophication and acidification (Lamers et al. 2015). They are often fed by groundwater, and can be Ca-rich and/or Fe-rich, depending on geological substrate, hydrology and water chemistry.

Nutrient availability in mineral-rich fens has been studied rather extensively in the past (e.g., Boyer and Wheeler 1989; Verhoeven et al. 1990; Snowden and Wheeler 1993, 1995; Wassen et al. 2005; Kooijman and Paulissen 2006). However, recent studies have provided controversial insights, especially related to availability of P in Fe-rich fens (Zak et al. 2008; Aggenbach et al. 2013; Pawlikowski et al. 2013; Cusell et al. 2014; van der Grift et al. 2016; Emsens et al. 2017).

Iron-rich soils are generally seen as P-limited, due to proposed stable $\mathrm{P}$ binding at $\mathrm{Fe}$ compounds (Walker and Syers 1976; Hamad et al. 1992). In aquatic ecosystems, P-poor water and high plant diversity are associated with high Fe:P ratios in water and soil (e.g., Geurts et al. 2008). The principle of $P$ capture by $F e$ is even used in phosphate removal from polluted surface water or agricultural runoff (Thistleton et al. 2001; Zou et al. 2018). In Fe-rich fens, sorption of $\mathrm{P}$ to, or precipitation with $\mathrm{Fe}$ may thus be an important mechanism to reduce Pavailability in soil pore water (Zak et al. 2004). When anoxic, Fe-rich groundwater is aerated, precipitation of iron hydroxyphosphates may even precede formation of iron (hydr)oxides as long as dissolved orthophosphate is present (van der Grift et al. 2016).

However, in semi-terrestrial Fe-rich peat soils, $\mathrm{P}$ availability may not be low at all. Recent studies showed that $P$ in vegetation and/or soil increased with $\mathrm{Fe}$ content of the peat soil instead of decreased, which would hamper restoration of formerly drained Fe-rich fens (Aggenbach et al. 2013; Pawlikowski et al. 2013; Emsens et al. 2017). In their studies, foliar N:P ratios dropped below the critical level of $14.5 \mathrm{~g} \mathrm{~g}^{-1}$, which do not point to $\mathrm{P}$ limitation, but to excess of $\mathrm{P}$ (Olde Venterink et al. 2003). High $P$ availability in Fe-rich fens may be caused by permanently high water levels, which leads to anoxic conditions, reduction of Fe(III) and mobilization of Fe-bound P (Patrick and Khalid 1974; Lamers et al. 2012), However, high plant $P$ contents and foliar N:P ratios below $10 \mathrm{~g} \mathrm{~g}^{-1}$ were found in Fe-rich soils even under well-drained conditions (Emsens et al. 2017), so other factors play a role as well. In Fe-rich fens, $\mathrm{P}$ availability to the vegetation could also increase if a large part of the $\mathrm{P}$ is sorbed to complexes of $\mathrm{Fe}$ and organic matter (OM), rather than to $\mathrm{Fe}$ (hydr)oxides (Kooijman et al. 2009; Gerke 2010; van der Grift et al. 2016). Sorption of P to Fe-OM complexes provides a weaker form of binding, but is often ignored in studies about P-availability (Gerke 2010, 2015).

Even though $P$ availability to the vegetation may be higher than expected in Fe-rich fens, it is unclear whether such a high $\mathrm{P}$ availability in Fe-rich fens actually leads to higher biomass production and light limitation to smaller fen species (Aggenbach et al. 2013). Emsens et al. (2017) showed that the total amount of $P$ in the aboveground vegetation clearly increased with Fe content of the soil, but aboveground biomass itself seemed less affected. In addition, Cusell et al. (2014) showed that aboveground biomass production in Fe-rich fens did not increase when fertilized with $P$, while Pawlikowski et al. (2013) did not find differences in aboveground biomass between $\mathrm{Ca}$-rich and $\mathrm{Fe}$-rich fens.

For Ca-rich fens, views on P-availability to the vegetation are less ambiguous. Ca-rich fens are generally regarded as P limited (e.g., Boyer and Wheeler 1989; Wassen et al. 2005; Pawlikowski et al. 2013; Cusell et al. 2014; Kooijman et al. 2016), and eutrophication with $\mathrm{P}$ is considered to be a major threat to plant diversity (Kooijman and Paulissen 2006; Lamers et al. 2015). However, the mechanisms for low $\mathrm{P}$ availability in $\mathrm{Ca}$ rich fens are not always clear. Calcium phosphates becomes coprecipitated with calcium carbonates in fens 
with Ca-rich groundwater (Boyer and Wheeler 1989), which are sparingly soluble around $\mathrm{pH} 7$ (Lindsay and Moreno 1966; Hinsinger 2001). However, in many Carich fens, Ca-concentrations are often too low for calcite precipitation. In the view of Emsens et al. (2017), these fens may be limited by P due to low Fe levels and low Psorption capacity, rather than high Ca contents.

The goal of the present study was to further unravel the regulation of $\mathrm{P}$ availability to the vegetation in different mineral-rich fens. We studied 25 mesotrophic and undrained mineral-rich fens over gradients from 0.2 to $8.1 \mathrm{~mol} \mathrm{~kg}^{-1} \mathrm{Ca}$ in the soil and from 0.02 to $2.2 \mathrm{~mol} \mathrm{~kg}^{-1}$ Fe. In order to test whether relationships between P, Fe and $\mathrm{Ca}$ differed between regions, 12 fens were selected in undisturbed areas in central Sweden, and 13 in areas with high human impact in the Netherlands. In each fen, we studied plant species composition, aboveground biomass, pore water and peat soil chemistry. We also measured different soil fractions of $\mathrm{P}, \mathrm{Fe}$ and $\mathrm{Al}$, such as total $\mathrm{P}$, inorganic $\mathrm{P}$, organic $\mathrm{P}$, sorbed $\mathrm{P}$ and exchangeable $\mathrm{P}$, and total, inorganic and organic amorphous $\mathrm{Fe}$ and $\mathrm{Al}$. We included organic fractions, because organic $\mathrm{P}$ may be a major source of $\mathrm{P}$ to the vegetation in these ecosystems (Pérez Corona et al. 1996; Turner et al. 2007; Cheesman et al. 2014; Güsewell 2017), and organic $\mathrm{Fe}$ and $\mathrm{Al}$ are part of humic Fe-OM and Al-OM complexes, which show weaker $\mathrm{P}$ sorption than $\mathrm{Fe}$ and $\mathrm{Al}$ (hydr)oxides (Gerke 2010). The research questions were (1): Does $P$ availability to the vegetation differ with respect to $\mathrm{Fe}$ and/or $\mathrm{Ca}$ content of the peat soil, and between regions? (2) Does higher P availability to the vegetation in particular fen types lead to higher plant biomass and lower species richness?

\section{Methods}

Field survey

Vegetation, soil and pore water samples were collected at the end of August and beginning of September in 13 fens with varying contents of iron and calcium in the Netherlands and 12 in central Sweden (Table 1). Selection of the sites was based on the presence of bryophytes such as Calliergon giganteum (Schimp.) Kindb., Scorpidium scorpioides (Hedw.) Limpr., S. cossonii (Schimp.) Hedenäs and Hamatocaulis vernicosus (Mitt.) Hedenäs, which are characteristic for mesotrophic fens, and occur over a range of Ca-rich to Fe-rich habitats (Mettrop et al. 2018). In central Sweden, all fens were characterized by groundwater seepage areas, but Ca-rich fens were found in areas with limestone and marl parent materials, while Fe-rich fens were found in areas with granitic glacial deposits. In the Netherlands, most Fe-rich fens also occurred in groundwater seepage areas, although two were regularly flooded with Fe-rich river water. However, many Dutch sampling localities were located in areas without groundwater seepage. Instead, these fens were fed by nutrient-poor and baserich surface water.

For each of the 25 sites, species composition and cover percentages of vascular plants and bryophytes were recorded in a $10 \mathrm{~m}^{2}$ plot, with nomenclature according to Van Tooren and Sparrius (2007) for the first, and van der Meijden (2005) for the latter. In each plot, three subplots were randomly selected. In each subplot, height of the water level was measured relatively to the soil surface just beneath the living moss layer, except in two Dutch Fe-rich fens. In each subplot, living aboveground biomass of vascular plants was harvested in $25 \times 25 \mathrm{~cm}$ squares for further analysis. Pore water samples were collected from the upper $10 \mathrm{~cm}$ of the soil with Rhizon SMS soil moisture samplers with pore size of $0.45 \mu \mathrm{m}$, connected to vacuumed syringes of $50 \mathrm{~mL}$. In addition, peat soil samples were collected from the upper $10 \mathrm{~cm}$ of the peat soil, just below the living moss layer. Samples for bulk density were collected with a steel corer with a $100 \mathrm{ml}$ volume. All samples were collected in airtight plastic bags to avoid oxygen exposure, and stored at $4{ }^{\circ} \mathrm{C}$ until further analysis.

\section{Chemical composition}

Pore water $\mathrm{pH}$, electrical conductivity (EC) and alkalinity were measured on the day of sampling with standard electrodes and by titration down to $\mathrm{pH} 4.2$ by using $0.01 \mathrm{~mol} \mathrm{~L}^{-1} \mathrm{HCl}$. Subsamples were acidified with $1 \%$ $\mathrm{HNO}_{3}$ to prevent metal precipitation. Concentrations of o- $\mathrm{PO}_{4}{ }^{3-}, \mathrm{NO}_{3}{ }^{-}, \mathrm{NH}_{4}{ }^{+}, \mathrm{SO}_{4}{ }^{2-}, \mathrm{Cl}^{-}$and dissolved organic matter (DOC) were measured in the laboratory with an Skalar auto Analyzer (Westerman 1990). Unfortunately, $\mathrm{NH}_{4}{ }^{+}$and $\mathrm{NO}_{3}{ }^{-}$concentrations could not be measured in two of the Dutch Fe-rich fens. Also, in one of the subsamples of one of the Ca-rich fens in Sweden, $\mathrm{NO}_{3}{ }^{-}$ concentrations were unrealistically high (> $250 \mu \mathrm{mol} \mathrm{L}{ }^{-1}$ ), and mean values for $\mathrm{NO}_{3}{ }^{-}$in this site were based on the other two subsamples. Total concentrations of $\mathrm{P}, \mathrm{Ca}^{2+}, \mathrm{Fe}^{2+}, \mathrm{S}^{2-}, \mathrm{Mg}^{2+}, \mathrm{Al}^{3+}, \mathrm{Na}^{+}, \mathrm{K}^{+}, \mathrm{Zn}^{2+}$ and $\mathrm{Mn}^{3+}$ were measured for all subsamples with Perkin 
Table 1 Sampling localities of mineral-rich fens with different total $\mathrm{Fe}$ and $\mathrm{Ca}$ content in the peat soil $(0-10 \mathrm{~cm})$ in the Netherlands (NL) and central Sweden $(\mathrm{S})$

\begin{tabular}{|c|c|c|c|c|c|c|}
\hline Site & Region & Coordinates & Soil Fe mmol m ${ }^{-2}$ & Soil Ca mmol m ${ }^{-2}$ & $\log \mathrm{Fe}$ & $\log \mathrm{Ca}$ \\
\hline De Haeck & NL & $5208^{\prime} 59 \mathrm{~N} ; 0450^{\prime} 36 \mathrm{E}$ & 91 & 1199 & 1.95 & 3.08 \\
\hline Stobbenribben & NL & $5247^{\prime} 09 \mathrm{~N} ; 05$ 59'03 E & 102 & 2213 & 2.00 & 3.35 \\
\hline Kiersche Wiede & $\mathrm{NL}$ & $5241^{\prime} 48 \mathrm{~N} ; 06$ 07'57 E & 166 & 1928 & 2.22 & 3.28 \\
\hline Blauwe Hel & NL & $5200^{\prime} 48 \mathrm{~N} ; 0534^{\prime} 16 \mathrm{E}$ & 308 & 2135 & 2.49 & 3.33 \\
\hline Kikkerlanden & $\mathrm{NL}$ & $5239^{\prime} 45 \mathrm{~N} ; 0602^{\prime} 27 \mathrm{E}$ & 529 & 2526 & 2.72 & 3.40 \\
\hline Geleenbeekdal & NL & 50 55'34 N; 05 54'03 E & 609 & 3487 & 2.79 & 3.54 \\
\hline Veldweg & NL & $5241^{\prime} 29 \mathrm{~N} ; 0606^{\prime} 45 \mathrm{E}$ & 748 & 4865 & 2.87 & 3.69 \\
\hline Tienhoven South & NL & $5210^{\prime} 31 \mathrm{~N} ; 0559^{\prime} 01 \mathrm{E}$ & 750 & 1508 & 2.87 & 3.18 \\
\hline Tienhoven North & NL & $5210^{\prime} 31 \mathrm{~N} ; 05$ 59'01 E & 1085 & 1978 & 3.04 & 3.30 \\
\hline Bennekomse Meent & NL & $5200^{\prime} 22 \mathrm{~N} ; 0535^{\prime} 37 \mathrm{E}$ & 1139 & 3315 & 3.06 & 3.52 \\
\hline Veerslootlanden & NL & $5237^{\prime} 09 \mathrm{~N} ; 0608^{\prime} 15 \mathrm{E}$ & 3511 & 4528 & 3.54 & 3.66 \\
\hline Meppelerdieplanden & NL & $5240^{\prime} 05 \mathrm{~N} ; 06$ 07'37 E & 3580 & 2102 & 3.55 & 3.32 \\
\hline Meppeler Diep & NL & $5241^{\prime} 00 \mathrm{~N} ; 0608^{\prime} 51 \mathrm{E}$ & 8044 & 2992 & 3.91 & 3.48 \\
\hline Gulåstjårnen 2 & $\mathrm{~S}$ & $6329^{\prime} 17 \mathrm{~N} ; 14$ 53'48 E & 76 & 203,439 & 1.85 & 5.31 \\
\hline Gulåstjårnen 1 & $\mathrm{~S}$ & $6329^{\prime} 17 \mathrm{~N} ; 14$ 53'48 E & 167 & 124,325 & 2.22 & 5.09 \\
\hline Gulåstjårnen lake 1 & $\mathrm{~S}$ & $6329^{\prime} 17 \mathrm{~N} ; 1453^{\prime} 48 \mathrm{E}$ & 408 & 5497 & 2.62 & 3.74 \\
\hline Gulåstjårnen lake 2 & $\mathrm{~S}$ & $6329^{\prime} 17 \mathrm{~N} ; 14$ 53'48 E & 500 & 8425 & 2.70 & 3.93 \\
\hline Stormyran 3 & $\mathrm{~S}$ & $6313^{\prime} 15 \mathrm{~N} ; 16$ 09'22 E & 1503 & 1773 & 3.18 & 3.25 \\
\hline Stormyran 2 & $\mathrm{~S}$ & 63 13'15 N; 16 09'22 E & 1719 & 2513 & 3.23 & 3.40 \\
\hline Storflon 1 & $\mathrm{~S}$ & 63 13'33 N; 16 00'45 E & 4483 & 1338 & 3.65 & 3.13 \\
\hline Stormyran 1 & $\mathrm{~S}$ & $6313^{\prime} 15 \mathrm{~N} ; 16$ 09'22 E & 6427 & 2983 & 3.81 & 3.47 \\
\hline Flärkarna 1 & $\mathrm{~S}$ & $6304^{\prime} 01 \mathrm{~N} ; 1610^{\prime} 43 \mathrm{E}$ & 7652 & 4585 & 3.88 & 3.66 \\
\hline Flärkarna 2 & $\mathrm{~S}$ & $6304^{\prime} 01 \mathrm{~N} ; 1610^{\prime} 43 \mathrm{E}$ & 14,031 & 4063 & 4.15 & 3.61 \\
\hline Storflon 2 & $\mathrm{~S}$ & 63 13'33 N; $1600^{\prime} 45 \mathrm{E}$ & 15,346 & 2323 & 4.19 & 3.37 \\
\hline Kjällmyran & $\mathrm{S}$ & $6324^{\prime} 10 \mathrm{~N} ; 1434^{\prime} 07 \mathrm{E}$ & 18,947 & 3858 & 4.28 & 3.59 \\
\hline
\end{tabular}

$\mathrm{Log} \mathrm{Fe}$ and $\log \mathrm{Ca}$ in the soil are both based on the total amounts of Fe and Ca in the upper $10 \mathrm{~cm}$ of the peat soil in mmol $\mathrm{m}^{-2}$. For each site, total $\mathrm{Fe}$ and $\mathrm{Ca}$ contents are average values, based on three replicate samples

Elmer Inductively Coupled Plasma - Optical Emission Spectrometry (ICP-OES) spectroscopy (Westerman 1990). It is possible that $\mathrm{Fe}^{2+}$ concentrations in pore water samples of Fe-rich fens have been overestimated to some extent, due to oxidation of this element during the sampling process, and re-dissolution after the samples had been treated with $1 \% \mathrm{HNO}_{3}$. Dissolved organic $\mathrm{P}$ (DOP) was calculated as the difference between total dissolved $\mathrm{P}$ and $\mathrm{o}-\mathrm{PO}_{4}$. In one of the subsamples of one of the Dutch Ca-rich fens, total $\mathrm{P}, \mathrm{PO}_{4}{ }^{3-}$ and DOP concentrations were exceptionally high $\left(>10 \mu \mathrm{mol} \mathrm{L}^{-1}\right)$, and mean values for $\mathrm{P}$ in pore water in this site were based on the other two subsamples.

Vegetation samples were weighed after drying at $70{ }^{\circ} \mathrm{C}$ until constant weight, and ground. Total $\mathrm{C}$ and $\mathrm{N}$ contents were measured in dried vegetation samples, using a Elementar CHNS analyzer (Westerman 1990). In addition, dry plant material was digested for $50 \mathrm{~min}$ in a Perkin Elmer microwave with $\mathrm{HNO}_{3}(65 \%)$ and $\mathrm{HCl}$ (37\%), after which total $\mathrm{P}, \mathrm{Ca}, \mathrm{Fe}, \mathrm{S}, \mathrm{Mg}, \mathrm{Al}$ and $\mathrm{K}$ contents in diluted digestates were measured by ICP (Westerman 1990). For plant material, N, P and K contents were expressed in $\mathrm{g}$ rather than mol, because critical nutrient ratios, which are used as indicators of which type of nutrient is limiting plant growth, are generally given in $\mathrm{g} \mathrm{g}^{-1}$ (Olde Venterink et al. 2003). Critical levels are $14.5 \mathrm{~g} \mathrm{~g}^{-1}$ for N:P ratios, $2.1 \mathrm{~g} \mathrm{~g}^{-1}$ for $\mathrm{N}: \mathrm{K}$ ratios and $3.4 \mathrm{mg} \mathrm{g}^{-1}$ for $\mathrm{K}: \mathrm{P}$ ratios.

Dry weights and gravimetric moisture contents of the fresh peat soil samples were determined by drying at $70{ }^{\circ} \mathrm{C}$ until constant weight. Total organic matter $(\mathrm{OM})$ contents were estimated for all subsamples by loss-on-ignition at 
$550{ }^{\circ} \mathrm{C}$. Total $\mathrm{C}$ and $\mathrm{N}$ contents were measured in dried peat soil samples with a CHNS analyzer. In addition, total $\mathrm{P}, \mathrm{Ca}, \mathrm{Fe}, \mathrm{S}, \mathrm{Mg}, \mathrm{Al}$ and $\mathrm{K}$ contents were measured with microwave destruction (Westerman 1990). Samples of dry soil were digested for $50 \mathrm{~min}$ in a microwave with $4.0 \mathrm{~mL}$ $\mathrm{HNO}_{3}(65 \%)$ and $1.0 \mathrm{~mL} \mathrm{HCl} \mathrm{(37 \% ).}$

In one of the Dutch Ca-rich and one of the Dutch Ferich fens, one of the three subsample showed 3-8 times higher amounts of amorphous than total $\mathrm{Fe}$, which is impossible. These subsamples were discarded for all parameters, and mean values for these sites based on the other two subsamples.

\section{Fractionation of $\mathrm{P}, \mathrm{Fe}$ and $\mathrm{Al}$}

Different mobile $\mathrm{P}, \mathrm{Fe}$ and $\mathrm{Al}$ fractions were determined using established chemical extraction procedures. It must be noted that the interpretation of results must be undertaken with caution since both the extraction procedure as well as used chemicals causes some limitations (Kooijman et al. 1998, 2009). The P, Fe and Al fractions were measured on lyophilized peat soil samples in order to restrict redox sensitive reactions and to keep soil moisture contents equal. For the 75 subsamples of the 25 sites, we measured total $\mathrm{P}$, inorganic $\mathrm{P}$, organic $\mathrm{P}$ and sorbed $\mathrm{P}$. Total $\mathrm{P}$ content (after heating at $500{ }^{\circ} \mathrm{C}$ for $4 \mathrm{~h}$ ) and inorganic $\mathrm{P}$ content (not heated) were extracted with $0.5 \mathrm{M} \mathrm{H}_{2} \mathrm{SO}_{4}$, and measured colorimetrically (Westerman 1990). With this method, total P was on average $85 \%$ of the total P measured on dry soil with microwave destruction, but the two values highly correlated $\left(\mathrm{R}^{2}=0.97\right)$. Organic $\mathrm{P}$ was calculated as the difference between total and inorganic $\mathrm{P}$. Sorbed $\mathrm{P}$ was measured with $0.073 \mathrm{M} \mathrm{NH}_{4}$-oxalate/ $0.05 \mathrm{M}$ oxalic acid extraction at $\mathrm{pH} 3.0$ and subsequent element analysis by ICP (Schwertmann 1964).

Total P consisted of inorganic and organic $\mathrm{P}$, which each consisted of solid or stable and sorbed $\mathrm{P}$ fractions. These fractions could not be measured directly, but minimum and maximum estimates could be calculated for solid inorganic $\mathrm{P}$ such as calcium or iron phosphates, sorbed inorganic $\mathrm{P}$, stable organic $\mathrm{P}$ and sorbed organic $\mathrm{P}$, based on the overlap and differences between the measured amounts of inorganic, organic and sorbed $P$ (Kooijman et al. 2009). In many fens, sorbed $P$ was larger than inorganic $\mathrm{P}$, which means that at least part of the sorbed $\mathrm{P}$ was organic. In these fens, the difference between sorbed and inorganic $\mathrm{P}$ thus represented a minimum estimate of sorbed organic $\mathrm{P}$. The amount of sorbed $\mathrm{P}$ itself was considered as a maximum estimate of sorbed organic P. In three Ca-rich fens, however, sorbed $\mathrm{P}$ was smaller than inorganic $\mathrm{P}$, and larger than organic P. In that case, the minimum estimate of sorbed organic $\mathrm{P}$ was zero, and the maximum estimate the amount of organic P itself. When the minimum and maximum estimates of sorbed organic $\mathrm{P}$ were known, it was possible to calculate maximum and minimum estimates for sorbed inorganic $\mathrm{P}$, by subtracting the values for sorbed organic $\mathrm{P}$ from the total amount of sorbed $\mathrm{P}$. When minimum and maximum estimates of sorbed organic and inorganic $\mathrm{P}$ were known, it was also possible to calculate estimates for stable organic $\mathrm{P}$ and solid inorganic P, by subtracting the values for the sorbed fractions from the total amounts of organic or inorganic $\mathrm{P}$.

Exchangeable and EDTA-extractable P were measured with sequential extractions according to Golterman (1996) on the three subsamples of 9 sites in the Netherlands, and 12 sites in central Sweden. For this analysis, the Dutch sites Blauwe Hel, Geleenbeekdal, Tienhoven North and Bennekomse Meent were not included. For exchangeable P, freeze dried and chopped samples were shaken in $1 \mathrm{M} \mathrm{NH}_{4} \mathrm{Cl}$. After this, Febound $\mathrm{P}$ was measured in extracts with $0.05 \mathrm{M} \mathrm{Ca}-$ EDTA. After this, Ca-bound P, consisting of weakly sorbed inorganic and organic $\mathrm{P}$ to $\mathrm{Ca}$ compounds was measured in extracts with $0.1 \mathrm{M} \mathrm{Na}_{2}$-EDTA.

Total amorphous Fe and Al were measured for all 75 subsamples of all 25 sites with the oxalate extractions for sorbed P described above. As already mentioned, selective extractions give only a rough indication of different forms. Also, even though we tried to restrict oxidation by using lyophilized soil samples, the high amounts of Fe(III) measured in Fe-rich fens could to some extent have originated from Fe(II) compounds. We also analyzed organic $\mathrm{Fe}$ and $\mathrm{Al}$, which are part of complexes with $\mathrm{Fe}, \mathrm{Al}$ and organic matter (OM), and lead to weaker $\mathrm{P}$ sorption than to $\mathrm{Fe}$ and $\mathrm{Al}$ oxides (Kooijman et al. 2009; Gerke 2010). Organic Fe and Al were measured according to McKeague et al. (1971) in $0.1 \mathrm{M} \mathrm{Na}_{4} \mathrm{P}_{2} \mathrm{O}_{7}$ extracts with the Auto Analyzer. Inorganic amorphous $\mathrm{Fe}+\mathrm{Al}$, present in amorphous oxides and phosphates, were calculated as the difference between total amorphous and organic $\mathrm{Fe}+\mathrm{Al}$. Part of the organic $\mathrm{Fe}+\mathrm{Al}$ may consist of small inorganic $\mathrm{Fe}+$ Al particles, especially in Fe-rich soils with mobilization and precipitation of Fe (Jeanroy and Guillet 1981). These particles probably mostly consist of fine colloids 
of iron hydroxides, associated with some organic matter, which are important to $\mathrm{P}$ binding (Bol et al. 2016). In any case, in Fe-rich dunes, the amount of plant-available $\mathrm{P}$ positively correlated with the fraction of so-called organic, pyrophosphate-extractable $\mathrm{Fe}$, and negatively with inorganic Fe (Kooijman et al. 2009).

\section{Statistical analysis}

The 25 vegetation relevés were clustered with Twinspan (Hill 1979), with standard options. The statistical analysis of all other parameters was based on mean values for each of the 25 sites, or 21 sites in the case of exchangeable, Ca-EDTA and Na-EDTA extractable P. For each parameter except number of plant species, mean values were based on the three subsamples measured in each site. Potential effects of $\mathrm{Ca}$ and $\mathrm{Fe}$ content of the soil, as well as region, were tested with stepwise multiple linear regressions, with $\log \mathrm{Fe}, \log \mathrm{Ca}$ and region as explanatory variables (Cody and Smith 1987). Log $\mathrm{Fe}$ and $\log \mathrm{Ca}$ in the soil were both based on the total amounts of $\mathrm{Fe}$ and $\mathrm{Ca}$ in the upper $10 \mathrm{~cm}$ of the peat soil, given in $\mathrm{mmol} \mathrm{m} \mathrm{m}^{-2}$. Univariate relationships between individual parameters were further tested with Pearson correlation tests. Most parameters showed linear relationships with soil $\mathrm{Fe}$ and/or $\mathrm{Ca}$, but for total and inorganic amorphous $\mathrm{Fe}+\mathrm{Al}$, second order relationships were more appropriate.

\section{Results}

Plant diversity and biomass

We encountered 46 bryophyte and 151 vascular plant species in the vegetation in total. In the first Twinspan division, fens in the Netherlands were separated from those in central Sweden (Table 2). This distinction was primarily based on plant species with different distribution patterns. In the Netherlands, temperate species prevailed, such as the EU-habitat directive species Liparis loeselii, which does not occur in Sweden at all, and the bryophyte Calliergonella cuspidate, which only occurs in the southern part. In central Sweden, boreal species were more common, such as Trichophorum alpinum and Paludella squarrosa, which are absent from the Netherlands. In both regions, the fens were separated into relatively Fe-poor and Fe-rich ones.
Aboveground vascular plant biomass also differed between the Netherlands and central Sweden, with higher values for the first, possibly due to the more temperate climate (Table 3, Fig. 1). However, plant species richness did not differ between regions. The total number of plant species ranged around 27 in both the Netherlands and central Sweden, although the number of bryophytes was significantly higher in the latter. Total plant species number did also not change with $\mathrm{Fe}$ or $\mathrm{Ca}$ in the soil, although the number of herb species was significantly lower in Ca-rich fens. Even though cover of the herb layer was significantly lower in Ca-rich fens, aboveground vascular plant biomass did also not differ between $\mathrm{Fe}$-poor and $\mathrm{Fe}$-rich fens, or $\mathrm{Ca}$-poor and $\mathrm{Ca}-$ rich fens.

\section{Vascular plant nutrients}

Plant nutrient contents strongly correlated with soil Fe, but did not differ between regions or with Ca content of the soil (Table 4). Plant N, P and K contents were all significantly higher in Fe-rich than in Fe-poor fens. Iron content of the soil especially correlated with plant $\mathrm{P}$ contents, which more than quadrupled from Fe-poor to Fe-rich fens (Fig. 2). Vascular plant N:P ratios also clearly correlated with Fe content of the soil. Values decreased from approximately $25 \mathrm{~g} \mathrm{~g}^{-1}$ in Fe-poor fens, which point to $\mathrm{P}$ limitation, to $10 \mathrm{~g} \mathrm{~g}^{-1}$ in Fe-rich fens, which indicate that $\mathrm{P}$ is not all a limiting factor for plant growth. The plants showed balanced N:P ratios of $15 \mathrm{~g} \mathrm{~g}^{-1}$ around $\log \mathrm{Fe}$ values of 3.7, or total Fe contents of $5000 \mathrm{mmol} \mathrm{m}^{-2}$.

However, although plant $\mathrm{P}$ contents clearly increased with soil $\mathrm{Fe}$, the total amount of $\mathrm{P}$ in aboveground vascular plant biomass did not differ between Fe-poor and Fe-rich fens, probably because vascular plant biomass was not affected by soil Fe. For the entire dataset, the correlation between soil $\mathrm{Fe}$ and total plant $\mathrm{P}$ showed a $\mathrm{R}^{2}$ value of 0.12 . In the stepwise multiple regression for total plant $\mathrm{P}, \log \mathrm{Fe}$ came out after region, and showed significant additional effects only in central Sweden.

Pore water characteristics

At the time of sampling, the water table did not differ with soil $\mathrm{Ca}$ or $\mathrm{Fe}$ content, or between regions, and was close to the surface in all fens (Table 5). The $\mathrm{pH}$ of the pore water increased with $\mathrm{Ca}$ content in the soil, with values ranging from 6.2 in $\mathrm{Ca}$-poor fens to 7.2 in $\mathrm{Ca}$ - 
Table 2 Twinspan clustering of mineral-rich fens with different soil $\mathrm{Fe}$ and $\mathrm{Ca}$ content in the Netherlands and central Sweden. Eigenvalues were 0.567 at the first division, 0.464 at the second division, and 0.420 at the third division. In the first division, the two regions were completely separated. In the second and third divisions, for both countries, Fe-rich fens were separated from Fepoor fens. Only species with frequency of $50 \%$ in at least one of the groups are listed

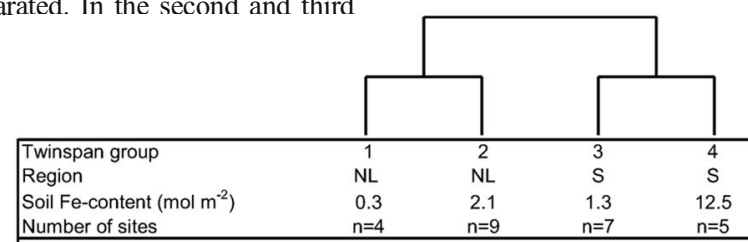

Vascular plants

Liparis loeselii

Thelypteris palustris

Eupatorium cannabinum

Galium uliginosus

Lysimachia thyrsiflora

Myrica gale

Typha angustifolia

Lythrum salicaria

Cirsium palustre

Hydrocotyle vulgaris

Mentha aquatica

Lysimachia vulgaris

Peucedanum palustre

Viola palustris

Juncus subnodulosus

Carex diandra

Alnus glutinosa

Calamagrostis canescens

Agrostis canina

Juncus articulatus

Ranunculus flammula

Drosera rotundifolia

Betula pubescens

Galium palustre

Pedicularis palustris

Carex lasiocarpa

Potentilla erecta

Equisetum palustre

Menyanthes trifoliata

Equisetum fluviatile

Phragmites australis

Utricularia minor

Molinia caerulea

Potentilla palustre

Salix cinerea

Carex panicea

Carex nigra

Carex rostrata

Betula pendula

Carex chordorrhiza

Carex limosa

Oxycoccus palustris

Dactylorhiza incarnata

Salix myrsinites

Trichophorum alpinum

Rumex acetosa

$\mathrm{n}=7 \quad \mathrm{n}=5$

Bryophytes

Sphagnum subnitens

Calliergonella cuspidata

Sphagnum contortum

Bryum pseudotriquetrum

Campylium stellatum

Calliergon giganteum

Scorpidium cossonii

Fissidens adiantoides

Scorpidium scorpioides

Hamatocaulis vernicosus

Sphagnum teres

Straminergon stramineum

Aneura pinguis

Paludella squarrosa

Tomentypnum nitens

Sphagnum warnstorfia

Drepanocladus trifarium

Helodium blandowii

\begin{tabular}{|c|c|c|c|}
\hline 75 & - & - & - \\
\hline 75 & - & - & - \\
\hline 50 & - & - & - \\
\hline 50 & - & - & - \\
\hline 50 & - & - & - \\
\hline 50 & - & - & - \\
\hline 50 & - & - & - \\
\hline 50 & - & - & - \\
\hline 100 & 56 & - & - \\
\hline 100 & 22 & - & - \\
\hline 75 & 78 & - & - \\
\hline 75 & 67 & - & - \\
\hline 75 & 44 & - & - \\
\hline 75 & 33 & - & - \\
\hline 75 & 11 & - & - \\
\hline 50 & 44 & - & - \\
\hline 50 & 22 & - & - \\
\hline 50 & 11 & - & - \\
\hline 50 & 11 & - & - \\
\hline 25 & 67 & - & - \\
\hline- & 78 & - & - \\
\hline - & 56 & - & - \\
\hline 75 & - & 43 & - \\
\hline 50 & - & 14 & - \\
\hline - & 67 & - & 20 \\
\hline 50 & 67 & 57 & 60 \\
\hline 50 & 44 & 100 & 60 \\
\hline 50 & 11 & 14 & 20 \\
\hline 25 & 22 & 29 & 60 \\
\hline 25 & 89 & 43 & 100 \\
\hline 25 & 67 & 43 & 80 \\
\hline 100 & 67 & 14 & - \\
\hline 50 & 22 & 14 & - \\
\hline 50 & 11 & 43 & - \\
\hline 75 & 78 & - & 20 \\
\hline 75 & 11 & - & 20 \\
\hline - & 44 & 100 & - \\
\hline - & 56 & 57 & 20 \\
\hline- & 56 & 86 & 100 \\
\hline - & - & 14 & 60 \\
\hline - & - & 29 & 80 \\
\hline - & - & 29 & 60 \\
\hline - & - & 43 & 80 \\
\hline - & - & 57 & 40 \\
\hline - & - & 57 & 20 \\
\hline - & - & 71 & 80 \\
\hline- & - & - & 60 \\
\hline 50 & - & - & - \\
\hline 100 & 89 & - & - \\
\hline 50 & - & 43 & - \\
\hline 100 & 22 & 71 & 60 \\
\hline 100 & 22 & 100 & 40 \\
\hline 50 & 44 & 14 & 80 \\
\hline 25 & 33 & 86 & 60 \\
\hline 75 & 11 & 14 & - \\
\hline 75 & 22 & 86 & - \\
\hline 25 & 44 & - & 100 \\
\hline 50 & - & 14 & 60 \\
\hline 25 & - & - & 60 \\
\hline 25 & - & 71 & 20 \\
\hline - & - & 14 & 80 \\
\hline - & - & 14 & 80 \\
\hline - & - & 29 & 60 \\
\hline- & - & 57 & - \\
\hline - & - & - & 60 \\
\hline
\end{tabular}


Table 3 Stepwise multiple linear regression of vegetation characteristics, with $\mathrm{Fe}$ and $\mathrm{Ca}$ content of the soil and region as explanatory variables. The analysis is based on 25 samples from the Netherlands and central Sweden, all based on three subreplicates

\begin{tabular}{lllll}
\hline Variable & $\mathrm{R}^{2} \log$ Fe soil & $\mathrm{R}^{2} \log$ Ca soil & $\mathrm{R}^{2}$ region & Total $^{2}$ \\
\hline Vascular plant biomass & 0.02 & 0.03 & $\mathbf{0 . 3 0}$ & $0.35^{* *}$ \\
Herb cover & - & $\mathbf{0 . 3 6}$ & - & $0.36^{* *}$ \\
Moss cover & 0.06 & 0.02 & 0.10 & $0.18^{\mathrm{ns}}$ \\
Total species number & - & - & 0.10 & $0.10^{\mathrm{ns}}$ \\
Number of herb species & - & $\mathbf{0 . 3 7}$ & - & $0.37^{* *}$ \\
Number of moss species & 0.03 & 0.03 & $\mathbf{0 . 1 9}$ & $0.25^{*}$ \\
\hline
\end{tabular}

$\log \mathrm{Fe}$ and $\log \mathrm{Ca}$ in the soil are both based on the total amounts of $\mathrm{Fe}$ and $\mathrm{Ca}$ in the upper $10 \mathrm{~cm}$ of the peat soil in $\mathrm{mmol} \mathrm{m}^{-2} . \mathrm{Ns}=$ not significant; $*=p<0.05 ; * *=p<0.01 ; * * *=p<0.001$. Variables explaining more than $17 \%$ of the variance in a particular parameter are given in bold

rich fens, but did not differ between regions or with soil Fe. Alkalinity was not correlated with region, soil Fe or Ca content, but ranged around $2.2 \mathrm{~mol} \mathrm{~L}^{-1}$ in all fens. Electrical conductivity however clearly differed between regions, with average values of $209 \mu \mathrm{S} \mathrm{cm}^{-1}$ in
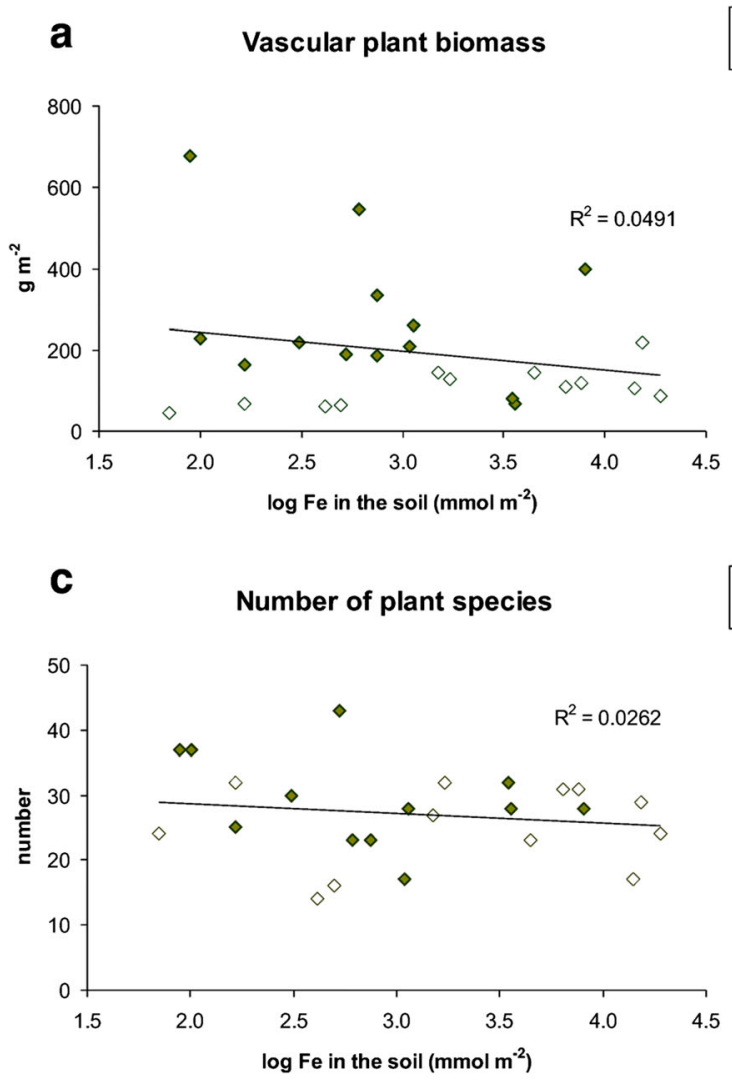

Fig. 1 Total number of plant species and vascular plant biomass in mineral-rich fens in the Netherlands and central Sweden in relation to the gradients in $\mathrm{Fe}$ and $\mathrm{Ca}$ in the soil. $\mathrm{Log} \mathrm{Fe}$ and $\log$ $\mathrm{Ca}$ are both based on the amounts of $\mathrm{Fe}$ and $\mathrm{Ca}$ in the upper $10 \mathrm{~cm}$ of the peat soil, expressed in $\mathrm{mmol} \mathrm{m} \mathrm{m}^{-2}$. $\mathrm{A}=$ vascular plant central Sweden, and $374 \mu \mathrm{S} \mathrm{cm}{ }^{-1}$ in the Netherlands. This was associated with higher $\mathrm{Na}^{+}, \mathrm{Cl}^{-}, \mathrm{SO}_{4}{ }^{2-}$ and DOC concentrations in the Netherlands.

At the time of sampling, pore water $\mathrm{Ca}^{2+}$ concentrations were also lower in the Netherlands, with average
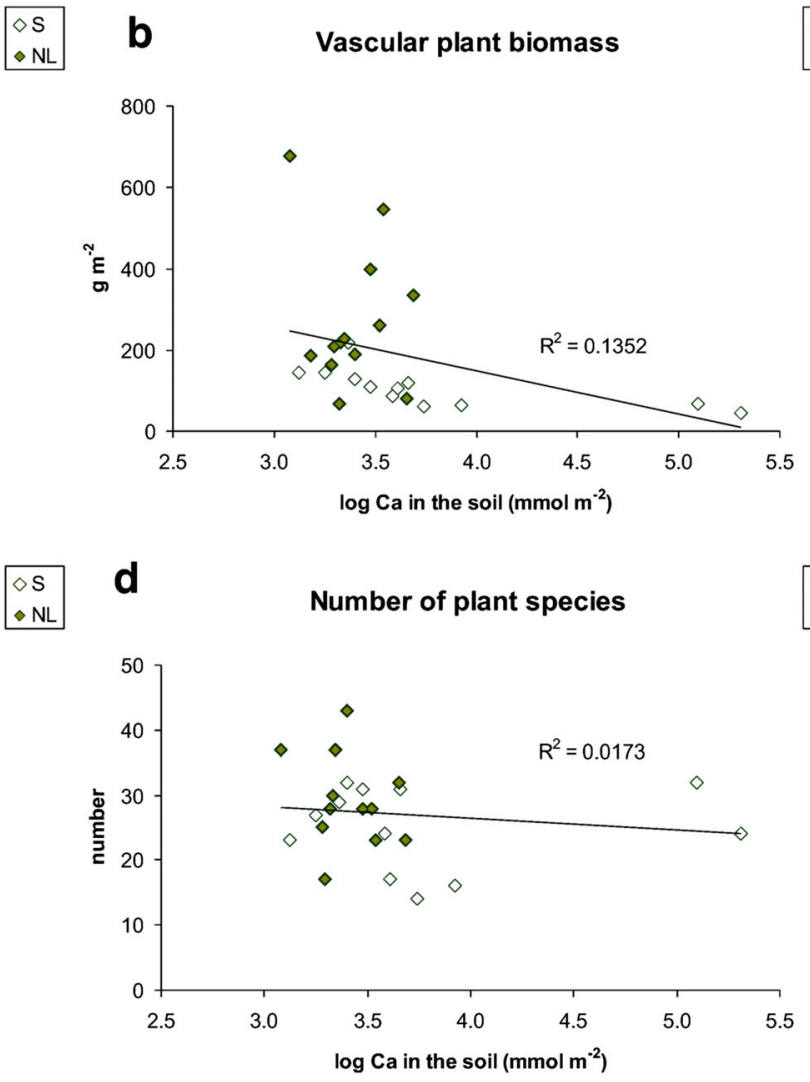

biomass in relation to soil $\mathrm{Fe}$; $\mathrm{B}=$ vascular plant biomass in relation to soil $\mathrm{Ca} ; \mathrm{C}=$ number of plant species in relation to soil Fe; $\mathrm{D}=$ number of plant species in relation to soil $\mathrm{Ca}$. None of the correlations was significant $(\mathrm{p}<0.05)$ 
Table 4 Stepwise multiple linear regression of plant nutrients, with Fe and Ca content of the soil and region as explanatory variables. The analysis is based on 25 samples from the Netherlands and central Sweden, all based on three subreplicates

\begin{tabular}{|c|c|c|c|c|}
\hline Variable & $\mathrm{R}^{2} \log$ Fe soil & $\mathrm{R}^{2} \log$ Ca soil & $\mathrm{R}^{2}$ region & Total $\mathrm{R}^{2}$ \\
\hline Plant $\mathrm{N}$-content $\left(\mathrm{mg} \mathrm{g}^{-1}\right)$ & 0.22 & 0.12 & 0.08 & $0.41 *$ \\
\hline Plant P-content $\left(\mathrm{mg} \mathrm{g}^{-1}\right)$ & 0.36 & 0.04 & 0.02 & $0.43 * *$ \\
\hline Plant K-content $\left(\mathrm{mg} \mathrm{g}^{-1}\right)$ & 0.25 & - & - & $0.25^{*}$ \\
\hline Plant Fe-content $\left(\mathrm{g} \mathrm{g}^{-1}\right)$ & - & 0.09 & 0.03 & $0.13^{\mathrm{ns}}$ \\
\hline Total plant $\mathrm{P}\left(\mathrm{g} \mathrm{m}^{-2}\right)$ & 0.24 & - & 0.15 & $0.40 * *$ \\
\hline Total plant $\mathrm{N}\left(\mathrm{g} \mathrm{m}^{-2}\right)$ & 0.04 & - & 0.36 & $0.40 * *$ \\
\hline Total plant $\mathrm{K}\left(\mathrm{g} \mathrm{m}^{-2}\right)$ & - & 0.15 & 0.06 & $0.21^{\mathrm{ns}}$ \\
\hline Total plant $\mathrm{Fe}\left(\mathrm{g} \mathrm{m}^{-2}\right)$ & - & 0.10 & - & $0.10^{\mathrm{ns}}$ \\
\hline Plant N:P ratio $\left(\mathrm{g} \mathrm{g}^{-1}\right)$ & 0.35 & 0.02 & 0.05 & $0.42 * *$ \\
\hline Plant $\mathrm{N}: \mathrm{K}$ ratio $\left(\mathrm{g} \mathrm{g}^{-1}\right)$ & 0.02 & - & 0.10 & $0.12^{\mathrm{ns}}$ \\
\hline Plant K:P ratio $\left(\mathrm{g} \mathrm{g}^{-1}\right)$ & 0.05 & 0.03 & 0.07 & $0.09^{\mathrm{ns}}$ \\
\hline Plant P:Fe ratio $\left(\mathrm{g} \mathrm{g}^{-1}\right)$ & 0.02 & 0.13 & 0.02 & $0.17^{\mathrm{ns}}$ \\
\hline
\end{tabular}

$\mathrm{Log} \mathrm{Fe}$ and $\log \mathrm{Ca}$ in the soil are both based on the total amounts of $\mathrm{Fe}$ and $\mathrm{Ca}$ in the upper $10 \mathrm{~cm}$ of the peat soil in $\mathrm{mmol} \mathrm{m}{ }^{-2}$. Ns $=$ not significant; $*=p<0.05 ; * *=p<0.01 ; * * *=p<0.001$. Variables explaining more than $17 \%$ of the variance in a particular parameter are given in bold
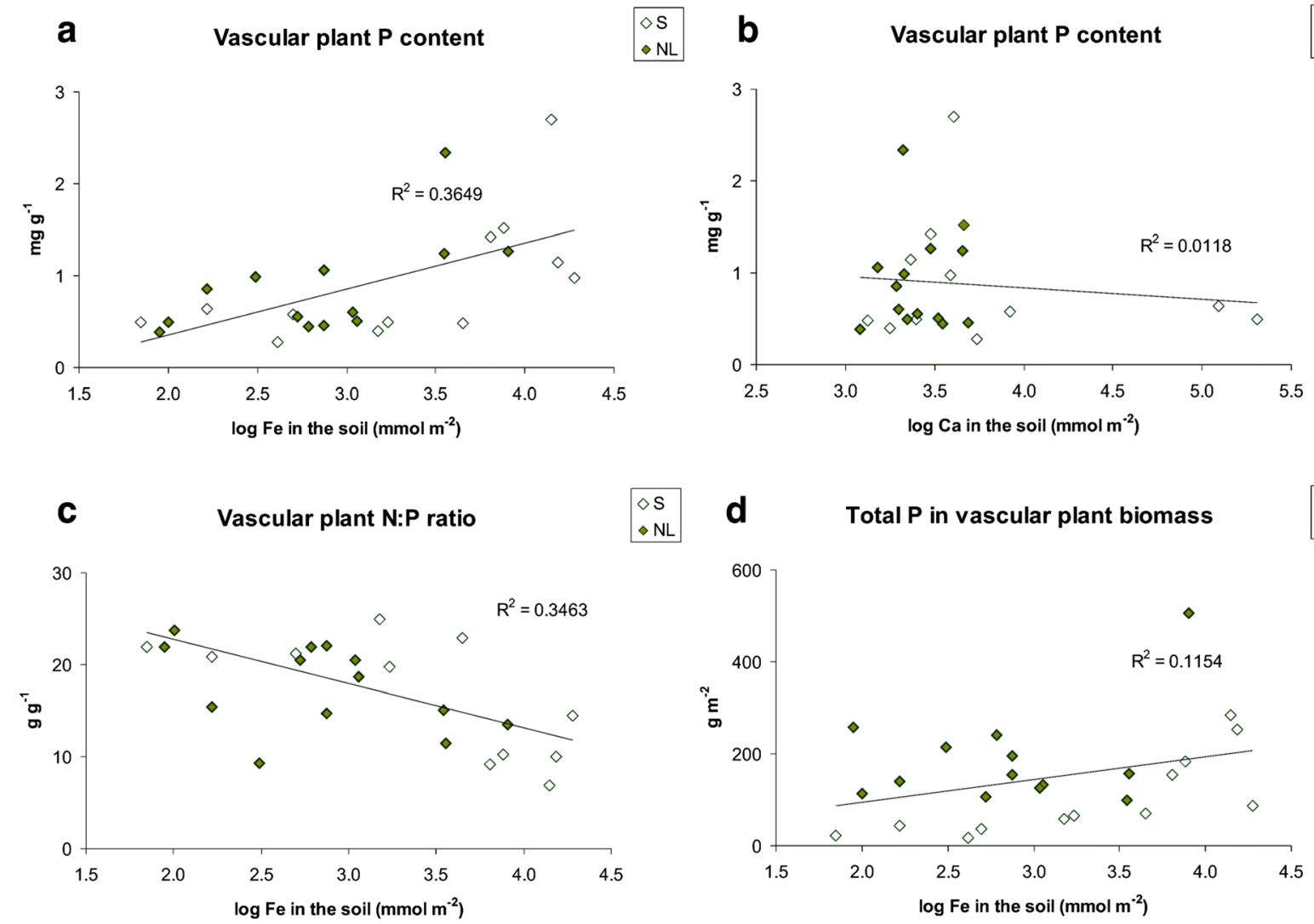

Fig. 2 Aboveground vascular plant P-content and N:P ratio in mineral-rich fens in the Netherlands and central Sweden in relation to the gradients in $\mathrm{Fe}$ and $\mathrm{Ca}$ in the soil. $\mathrm{Log} \mathrm{Fe}$ and $\log \mathrm{Ca}$ are both based on the total amounts of $\mathrm{Fe}$ and $\mathrm{Ca}$ in the upper $10 \mathrm{~cm}$ of the peat soil, expressed in $\mathrm{mmol} \mathrm{m}^{-2}$. $\mathrm{A}=$ plant $\mathrm{P}$ content in relation to

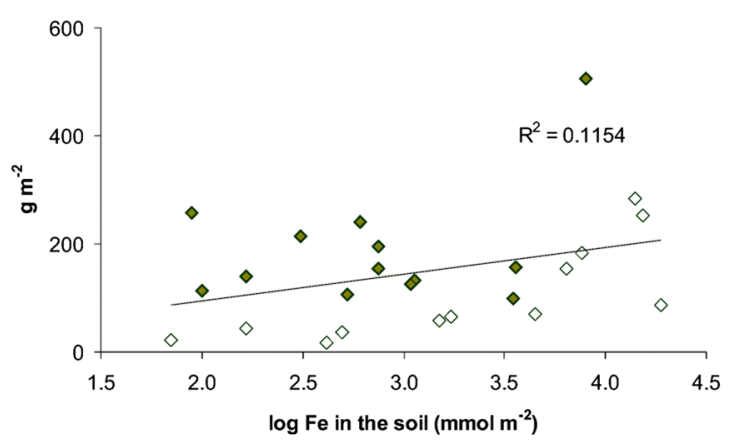

soil Fe; $\mathrm{B}=$ plant $\mathrm{P}$ content in relation to soil $\mathrm{Ca} ; \mathrm{C}=$ plant $\mathrm{N}: \mathrm{P}$ ratio in relation to soil $\mathrm{Fe} ; \mathrm{D}=$ plant $\mathrm{N}: \mathrm{P}$ ratio in relation to soil $\mathrm{Ca}$. Correlations were only significant $(p<0.05)$ for vascular plant $\mathrm{P}$ content and N:P ratio with $\log \mathrm{Fe}$ 
Table 5 Stepwise multiple linear regression of pore water characteristics in the peat soil, with Fe and Ca content of the soil and region as explanatory variables. The analysis is based on 25 samples from the Netherlands and central Sweden, all based on three subreplicates

\begin{tabular}{|c|c|c|c|c|}
\hline Variable & $\mathrm{R}^{2} \log \mathrm{Fe}$ soil & $\mathrm{R}^{2} \log$ Ca soil & $\mathrm{R}^{2}$ region & Total $\mathrm{R}^{2}$ \\
\hline Water table & - & - & 0.07 & $0.07^{\mathrm{ns}}$ \\
\hline $\mathrm{pH}$ & 0.07 & 0.34 & - & $0.41 * *$ \\
\hline Alkaninity $\left(\mathrm{mmol} \mathrm{L}^{-1}\right)$ & - & - & 0.09 & $0.18^{\mathrm{ns}}$ \\
\hline $\mathrm{EC}\left(\mu \mathrm{S} \mathrm{cm}^{-1}\right)$ & - & 0.16 & 0.23 & $0.39 *$ \\
\hline $\mathrm{Na}\left(\mu \mathrm{mol} \mathrm{L}^{-1}\right)$ & - & - & 0.62 & $0.62 * * *$ \\
\hline $\mathrm{Cl}\left(\mu \mathrm{mol} \mathrm{L}{ }^{-1}\right)$ & 0.01 & 0.02 & 0.71 & $0.74 * * *$ \\
\hline $\mathrm{SO}_{4}(\mu \mathrm{mol} \mathrm{L}-1)$ & 0.11 & 0.07 & 0.27 & $0.45^{*}$ \\
\hline $\mathrm{DOC}\left(\mu \mathrm{mol} \mathrm{L}{ }^{-1}\right)$ & 0.04 & - & 0.34 & $0.38 * *$ \\
\hline $\mathrm{Ca}\left(\mu \mathrm{mol} \mathrm{L}{ }^{-1}\right)$ & - & 0.10 & 0.17 & $0.27 *$ \\
\hline $\operatorname{Mg}\left(\mu \mathrm{mol} \mathrm{L}{ }^{-1}\right)$ & 0.21 & 0.09 & 0.03 & $0.33 *$ \\
\hline $\mathrm{K}\left(\mu \mathrm{mol} \mathrm{L}{ }^{-1}\right)$ & - & - & 0.07 & $0.07^{\mathrm{ns}}$ \\
\hline $\mathrm{Fe}\left(\mu \mathrm{mol} \mathrm{L}{ }^{-1}\right)$ & 0.17 & - & 0.10 & $0.26^{*}$ \\
\hline $\mathrm{Al}\left(\mu \mathrm{mol} \mathrm{L}{ }^{-1}\right)$ & 0.07 & 0.03 & 0.10 & $0.21^{\mathrm{ns}}$ \\
\hline $\mathrm{NO}_{3}(\mu \mathrm{mol} \mathrm{L}-1)$ & - & - & 0.20 & $0.20 *$ \\
\hline $\mathrm{NH}_{4}(\mu \mathrm{mol} \mathrm{L}-1)$ & - & - & 0.11 & $0.11^{\mathrm{ns}}$ \\
\hline $\mathrm{PO}_{4}\left(\mu \mathrm{mol} \mathrm{L}{ }^{-1}\right)$ & 0.03 & - & 0.08 & $0.11^{\mathrm{ns}}$ \\
\hline $\mathrm{DOP}\left(\mu \mathrm{mol} \mathrm{L}{ }^{-1}\right)$ & 0.16 & - & - & $0.16^{\mathrm{ns}}$ \\
\hline
\end{tabular}

$\mathrm{Log} \mathrm{Fe}$ and $\log \mathrm{Ca}$ in the soil are both based on the total amounts of $\mathrm{Fe}$ and $\mathrm{Ca}$ in the upper $10 \mathrm{~cm}$ of the peat soil in $\mathrm{mmol} \mathrm{m}^{-2}$. $\mathrm{EC}=$ Electrical conductivity. Ns $=$ not significant; $*=p<0.05 ; * *=\mathrm{p}<0.01 ; * * *=\mathrm{p}<0.001$. Variables explaining more than $17 \%$ of the variance in a particular parameter are given in bold

values of $879 \mu \mathrm{mol} \mathrm{L}{ }^{-1}$ for central Sweden, and $1235 \mu \mathrm{mol} \mathrm{L}{ }^{-1}$ in the Netherlands, but also increased from Ca-poor to Ca-rich fens. Magnesium concentrations mainly differed with $\mathrm{Fe}$ in the soil, with higher values for Fe-poor fens, but $\mathrm{K}^{+}$was not correlated with region or soil types. Iron concentrations mainly differed with $\mathrm{Fe}$ in the soil, and increased from $\mathrm{Fe}$-poor to $\mathrm{Fe}$ rich fens from 2 to $160 \mu \mathrm{mol} \mathrm{L}{ }^{-1}$, but $\mathrm{Al}^{3+}$ concentrations were not affected.

At the time of sampling, nitrate concentrations were significantly higher in central Sweden than in the Netherlands, with average values of 2.8 and $1.5 \mu \mathrm{mol} \mathrm{L}^{-1}$ respectively, but did not differ with $\mathrm{Ca}$ or $\mathrm{Fe}$ content in the soil. Ammonium, phosphate and DOP concentrations did not differ between regions or along soil gradients at all.

\section{Soil characteristics}

Soil organic matter content showed significantly lower values in Ca-rich than in Ca-poor fens, due to precipitation of secondary calcium carbonates in Ca-rich fens (Table 6). However, most fens had high soil organic matter content, and average values were $79 \%$ for the Netherlands, and
$73 \%$ for central Sweden. Dry weight or bulk density of the peat soil also increased in Ca-rich fens, because calcium carbonates are heavier than organic matter. However, $\mathrm{N}$ content and $\mathrm{C}: \mathrm{N}$ ratio did not correlate with regions, soil $\mathrm{Fe}$ or Ca. Potassium contents of the peat soil were approximately two times higher in the Netherlands, and also increased from $\mathrm{Fe}$-poor to Fe-rich soils.

Phosphorus contents in the soil, and C:P and N:P ratios, mainly correlated with Fe content. Phosphorus contents, measured by microwave destruction, increased from Fe-poor to Fe-rich fens, and C:P and N:P ratios decreased (Fig. 3). Soil C:P ratios decreased from approximately $900 \mathrm{~g} \mathrm{~g}^{-1}$ in Fe-poor fens to less than $300 \mathrm{~g} \mathrm{~g}^{-1}$ in Fe-rich fens. Soil N:P ratios also showed a more than threefold decrease over this gradient.

$\mathrm{P}$ fractions in the soil

In the selective extractions, total soil $\mathrm{P}$ mainly correlated with $\mathrm{Fe}$ content, and showed a fourfold increase from $\mathrm{Fe}$-poor to Fe-rich fens (Table 7). Iron richness of the soil also affected organic P (Fig. 4). However, for inorganic $\mathrm{P}$, correlations with soil $\mathrm{Fe}$ 
Table 6 Stepwise multiple linear regression of soil characteristics $(0-10 \mathrm{~cm})$, with Fe and Ca content of the soil and region explanatory variables. The analysis is based on 25 samples from the Netherlands and central Sweden, all based on three subreplicates

\begin{tabular}{|c|c|c|c|c|}
\hline Variable & $\mathrm{R}^{2} \log$ Fe soil & $\mathrm{R}^{2} \log$ Ca soil & $\mathrm{R}^{2}$ region & Total $\mathrm{R}^{2}$ \\
\hline Organic matter $(\%)$ & - & 0.56 & - & $0.56^{* * * *}$ \\
\hline Dry weight $\left(\mathrm{kg} \mathrm{m}^{-2}\right)$ & - & 0.72 & - & $0.72 * * *$ \\
\hline Total N $\left(\mathrm{g} \mathrm{m}^{-2}\right)$ & - & - & - & - \\
\hline Total P $\left(\mathrm{g} \mathrm{m}^{-2}\right)$ & 0.28 & 0.12 & 0.08 & $0.47 * *$ \\
\hline Total $\mathrm{K}\left(\mathrm{g} \mathrm{m}^{-2}\right)$ & 0.13 & 0.08 & 0.21 & $0.42 *$ \\
\hline Soil C:N ratio $\left(\mathrm{g} \mathrm{g}^{-1}\right)$ & - & - & - & - \\
\hline Soil C:P ratio $\left(\mathrm{g} \mathrm{g}^{-1}\right)$ & 0.56 & - & 0.13 & $0.69 * * *$ \\
\hline Soil N:P ratio $\left(\mathrm{g} \mathrm{g}^{-1}\right)$ & 0.38 & - & 0.11 & $0.49 * *$ \\
\hline
\end{tabular}

$\mathrm{Log} \mathrm{Fe}$ and $\log \mathrm{Ca}$ in the soil are both based on the total amounts of $\mathrm{Fe}$ and $\mathrm{Ca}$ in the upper $10 \mathrm{~cm}$ of the peat soil in $\mathrm{mmol} \mathrm{m}^{-2}$. Total $\mathrm{P}$ is based on microwave destruction of the peat soil. Ns $=$ not significant; $*=p<0.05$; $* *=p<0.01 ; * * * p<0.001$. Variables explaining more than $17 \%$ of the variance in a particular parameter are given in bold

content were much lower, and not significant in the multiple linear regression, although they were just significant in the univariate analysis.
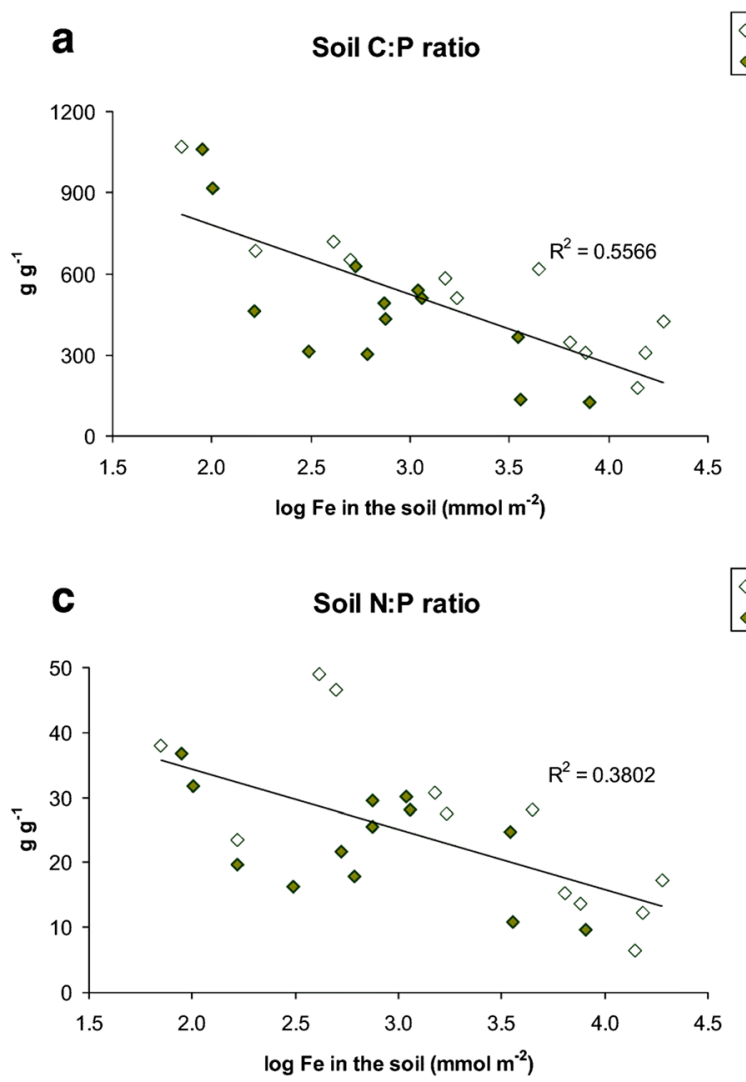

Fig. 3 Soil C:P and N:P ratio in mineral-rich fens in the Netherlands and central Sweden in relation to the gradients in $\mathrm{Fe}$ and $\mathrm{Ca}$ in the soil. $\log \mathrm{Fe}$ and $\log \mathrm{Ca}$ are both based on the total amounts of $\mathrm{Fe}$ and $\mathrm{Ca}$ in the upper $10 \mathrm{~cm}$ of the peat soil, expressed in $\mathrm{mmol} \mathrm{m}^{-2} . \mathrm{A}=$
Sorbed, oxalate-extractable P was more strongly correlated with Fe richness of the soil than organic or inorganic P. When expressed as fraction of total P,
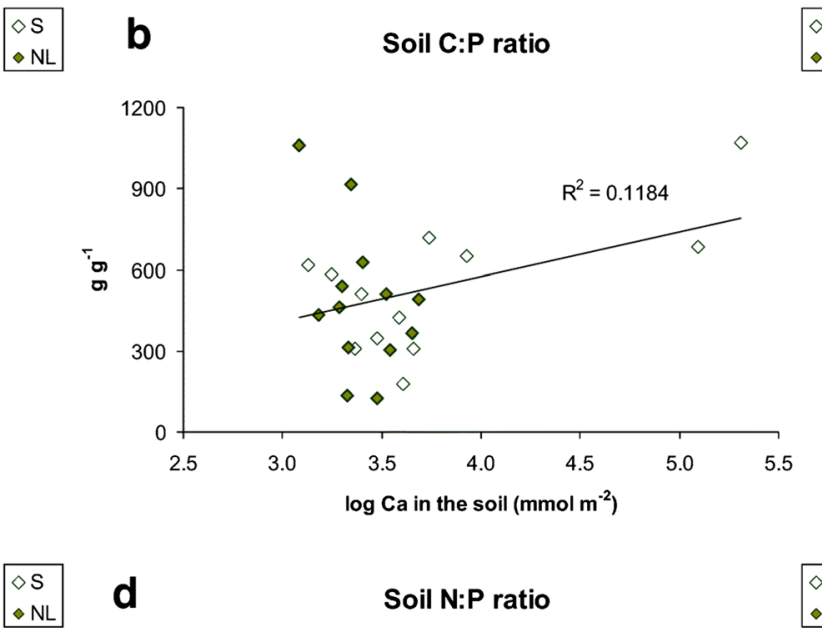

d

Soil N:P ratio

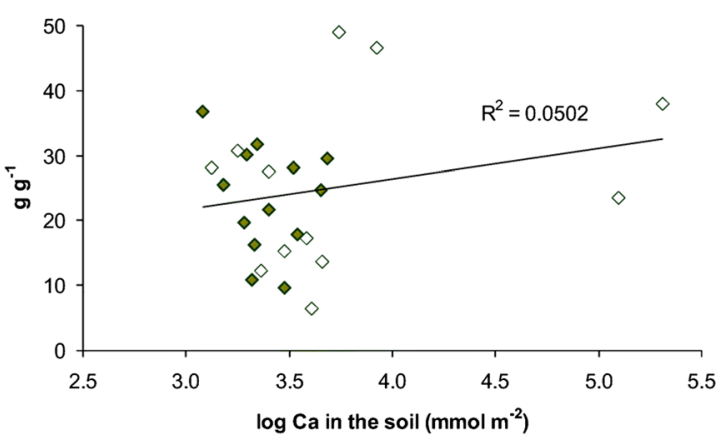

soil $\mathrm{C}: \mathrm{P}$ ratio in relation to soil $\mathrm{Fe} ; \mathrm{B}=$ soil $\mathrm{C}: \mathrm{P}$ ratio in relation to soil $\mathrm{Ca}$; $\mathrm{C}=$ soil $\mathrm{N}: \mathrm{P}$ ratio in relation to soil $\mathrm{Fe} ; \mathrm{D}=$ soil $\mathrm{N}: \mathrm{P}$ ratio in relation to soil $\mathrm{Ca}$. Correlations were significant $(p<0.05)$ for $\log \mathrm{Fe}$ (A and $\mathrm{C})$, but not for $\log \mathrm{Ca}(\mathrm{B}$ and $\mathrm{D})$ 
Table 7 Stepwise multiple linear regression of $\mathrm{P}, \mathrm{Fe}$ and $\mathrm{Al}$ fractions in the peat soil $(0-10 \mathrm{~cm})$, with $\mathrm{Fe}$ and $\mathrm{Ca}$ content of the soil and region as explanatory variables. For most parameters, the analysis is based on 25 samples from the Netherlands and central Sweden, all based on three subreplicates. However, exchangeable P, Ca-EDTA and Na-EDTA P were determined for 21 sites only

\begin{tabular}{|c|c|c|c|c|}
\hline Variable & $\mathrm{R}^{2} \log$ Fe soil & $\mathrm{R}^{2} \log$ Ca soil & $\mathrm{R}^{2}$ region & Total $\mathrm{R}^{2}$ \\
\hline Total P (mmol m$\left.{ }^{-2}\right)$ & 0.24 & 0.15 & 0.13 & $0.53^{*}$ \\
\hline Organic $\mathrm{P}\left(\mathrm{mmol} \mathrm{m}^{-2}\right)$ & 0.18 & 0.09 & 0.12 & $0.40^{*}$ \\
\hline Organic $\mathrm{P}(\%$ of total $\mathrm{P})$ & 0.07 & 0.16 & - & $0.23^{\mathrm{ns}}$ \\
\hline Inorganic $\mathrm{P}\left(\mathrm{mmol} \mathrm{m}^{-2}\right)$ & 0.15 & 0.08 & - & $0.23^{\mathrm{ns}}$ \\
\hline Inorganic $\mathrm{P}(\%$ of total $\mathrm{P})$ & 0.07 & 0.16 & - & $0.23^{\mathrm{ns}}$ \\
\hline Adsorbed $\mathrm{P}\left(\mathrm{mmol} \mathrm{m}^{-2}\right)$ & 0.25 & 0.10 & 0.11 & $0.46^{*}$ \\
\hline Adsorbed P (\% of total P) & 0.38 & 0.03 & 0.05 & $0.46^{* *}$ \\
\hline Ca-EDTA extractable $\mathrm{P}\left(\mathrm{mmol} \mathrm{m}^{-2}\right)$ & 0.57 & 0.04 & 0.09 & $0.70 * * *$ \\
\hline Na-EDTA extractable $\mathrm{P}\left(\mathrm{mmol} \mathrm{m}^{-2}\right)$ & 0.19 & 0.14 & 0.11 & $0.44 *$ \\
\hline Exchangeable $\mathrm{P}\left(\mathrm{mmol} \mathrm{m}^{-2}\right)$ & 0.05 & - & 0.32 & $0.38^{*}$ \\
\hline Exchangeable $\mathrm{P}(\%$ of sorbed $\mathrm{P})$ & 0.49 & 0.21 & - & $0.69 * * *$ \\
\hline Minimum estimate solid inorganic $\mathrm{P}(\%$ Total $\mathrm{P})$ & 0.03 & 0.79 & - & $0.82 * * *$ \\
\hline Maximum estimate solid inorganic $\mathrm{P}(\%$ Total $\mathrm{P})$ & - & 0.60 & - & $0.60 * * *$ \\
\hline Minimum estimate stable organic $\mathrm{P}(\%$ Total $\mathrm{P})$ & 0.20 & $\mathbf{0 . 2 0}$ & 0.02 & $0.42 *$ \\
\hline Maximum estimate stable organic $\mathrm{P}(\%$ Total $\mathrm{P})$ & 0.24 & 0.14 & 0.03 & $0.42 *$ \\
\hline Minimum estimate sorbed inorganic P (\% Total P) & 0.09 & - & - & $0.09^{\mathrm{ns}}$ \\
\hline Maximum estimate sorbed inorganic $\mathrm{P}(\%$ Total $\mathrm{P})$ & 0.04 & 0.04 & 0.08 & $0.16^{\mathrm{ns}}$ \\
\hline Minimum estimate sorbed organic $\mathrm{P}(\%$ Total $\mathrm{P})$ & 0.35 & 0.02 & 0.09 & $0.46^{* *}$ \\
\hline Maximum estimate sorbed organic P (\% Total P) & 0.42 & 0.11 & 0.03 & $0.55 * * *$ \\
\hline Total $\mathrm{Fe}$ and $\mathrm{Al}\left(\mathrm{mol} \mathrm{m}^{-2}\right)$ & 0.61 & 0.07 & 0.05 & $0.73 * * *$ \\
\hline Total amorphous $\mathrm{Fe}$ and $\mathrm{Al}\left(\mathrm{mol} \mathrm{m}^{-2}\right)$ & 0.77 & 0.02 & - & $0.79 * * *$ \\
\hline Organic $\mathrm{Fe}$ and $\mathrm{Al}\left(\mathrm{mol} \mathrm{m}^{-2}\right)$ & 0.71 & 0.03 & 0.04 & $0.77 * * *$ \\
\hline Organic $\mathrm{Fe}$ and $\mathrm{Al}(\%$ of amorphous $\mathrm{Fe}$ and $\mathrm{Al}$ ) & 0.45 & 0.04 & 0.02 & $0.51 * * *$ \\
\hline Inorganic $\mathrm{Fe}$ and $\mathrm{Al}\left(\mathrm{mol} \mathrm{m}^{-2}\right)$ & 0.61 & - & 0.05 & $0.66^{* * * *}$ \\
\hline Inorganic $\mathrm{Fe}$ and $\mathrm{Al}(\%$ of amorphous $\mathrm{Fe}$ and $\mathrm{Al})$ & 0.45 & 0.04 & 0.02 & $0.51 * * *$ \\
\hline
\end{tabular}

$\mathrm{Log} \mathrm{Fe}$ and $\log \mathrm{Ca}$ in the soil are both based on the total amounts of $\mathrm{Fe}$ and $\mathrm{Ca}$ in the upper $10 \mathrm{~cm}$ of the peat soil in $\mathrm{mmol} \mathrm{m}^{-2}$. Total $\mathrm{P}$ is based on extraction with $\mathrm{H}_{2} \mathrm{SO}_{4}$. Ns $=$ not significant; $*=\mathrm{p}<0.05 ; * *=\mathrm{p}<0.01 ; * * *=\mathrm{p}<0.001$. Variables explaining more than $17 \%$ of the variance in a particular parameter are given in bold

correlations between sorbed $\mathrm{P}$ and soil Fe were even higher. Sorbed $\mathrm{P}$ accounted for approximately $5 \%$ of total $\mathrm{P}$ in Fe-poor fens, but this value increased to $40 \%$ in Fe-rich fens. The increase in sorbed $\mathrm{P}$ with soil $\mathrm{Fe}$ was supported by Ca-EDTA extractable $\mathrm{P}$, and to some extent by Na-EDTA extractable $\mathrm{P}$, which mainly consist of sorbed P-fractions. However, exchangeable P was significantly higher for the Netherlands than for central Sweden, which may reflect the generally higher $\mathrm{P}$ inputs.

In many fens, sorbed $\mathrm{P}$ was higher than inorganic $\mathrm{P}$. In fact, only three fens showed higher values for inorganic than for sorbed P. All three fens were Fe-poor, and two of them belonged to the most Ca-rich fens. With the measurement of inorganic, organic and sorbed $\mathrm{P}$, and the overlap between them, minimum and maximum estimates could be calculated for different inorganic and organic P fractions (Fig. 5). For solid inorganic P, expressed as percentage of total $\mathrm{P}, \mathrm{Fe}$ in the soil was unimportant, but the amount of soil Ca explained $79 \%$ and $60 \%$ of its variance. Minimum estimates of solid inorganic $\mathrm{P}$ were substantially higher than zero only in the most extreme Ca-rich fens, which points to precipitation of calcium phosphates there.

Minimum and maximum estimates of stable organic $\mathrm{P}$ suggested that this fraction predominated in all fens. 

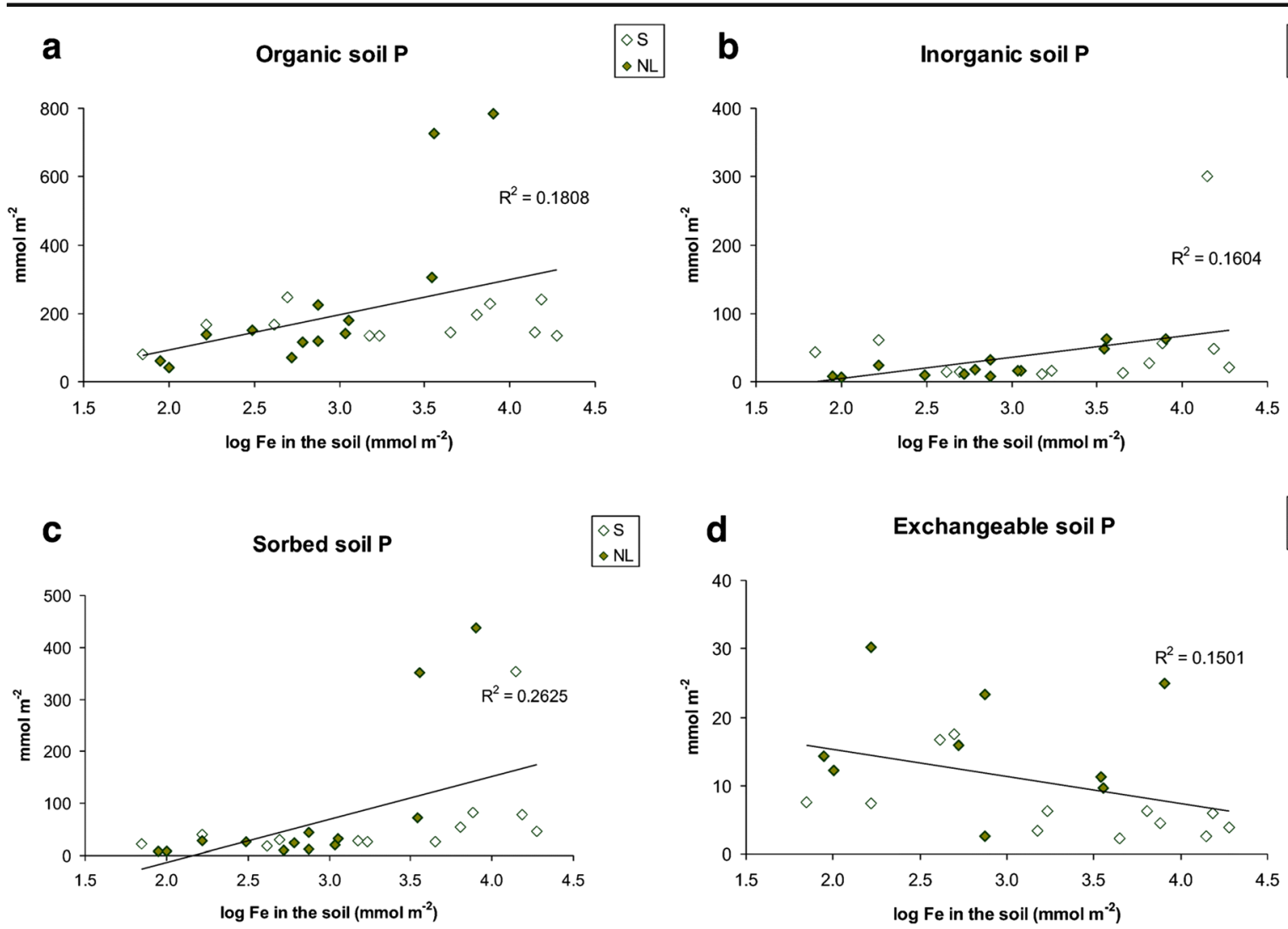

Fig. 4 Organic, inorganic, sorbed and exchangeable soil $\mathrm{P}$ in mineral-rich fens in the Netherlands and central Sweden in relation to $\mathrm{Fe}$ in the soil. $\mathrm{Log} \mathrm{Fe}$ is based on the total amounts of $\mathrm{Fe}$ in the upper $10 \mathrm{~cm}$ of the peat soil, expressed in $\mathrm{mmol} \mathrm{m}^{-2}$. A = organic

$\mathrm{P} ; \mathrm{B}=$ inorganic $\mathrm{P} ; \mathrm{C}=$ oxalate-extractable sorbed $\mathrm{P} ; \mathrm{D}=\mathrm{NH}_{4} \mathrm{Cl}-$ extractable exchangeable $\mathrm{P}$. All correlations were significant $(\mathrm{p}<0.05)$, except for exchangeable $\mathrm{P}$ (D)

Both estimates correlated with $\mathrm{Fe}$ and $\mathrm{Ca}$ in the soil, and increased to some extent from Ca-poor to Ca-rich fens, but significantly decreased from Fe-poor to Fe-rich fens.

In most fens, sorbed $\mathrm{P}$ was higher than inorganic $\mathrm{P}$, which means that at least part of the sorbed $\mathrm{P}$ was organic. The estimates of sorbed organic $\mathrm{P}$, expressed as percentage of total $\mathrm{P}$, did not differ between regions, or over gradients in soil Ca. However, both minimum and maximum estimates of sorbed organic $\mathrm{P}$ showed a clear increase with soil Fe. Estimates of sorbed organic $\mathrm{P}$ ranged between 0 and $10 \%$ of total $\mathrm{P}$ in Fe-poor fens, but $18-30 \%$ in Fe-rich fens. As total $\mathrm{P}$ also increased over this gradient, the actual increase in sorbed organic $\mathrm{P}$ from Fe-poor to Fe-rich fens was even higher. Also, when expressed as percentage of the amount of sorbed P, estimates of the organic P fraction increased from 0 to $21 \%$ of sorbed $\mathrm{P}$ in Fe-poor fens to 38-63\% in Fe-rich fens.

Estimates of sorbed inorganic $\mathrm{P}$, expressed as percentage of total $\mathrm{P}$, did not correlate with soil $\mathrm{Ca}, \mathrm{Fe}$ or

regions. However, when expressed as percentage of the amount of sorbed $\mathrm{P}$, sorbed inorganic $\mathrm{P}$ ranged between 79 and $100 \%$ of sorbed $\mathrm{P}$ in Fe-poor fens, to $37-62 \%$ in Fe-rich fens.

Total, inorganic and organic $\mathrm{Fe}+\mathrm{Al}$

Total amorphous $\mathrm{Fe}+\mathrm{Al}$, which represents the total $\mathrm{P}$ sorption capacity, highly correlated with Fe content of the peat soil (Fig. 6). Total P sorption capacity increased at $\log \mathrm{Fe}$ values higher than 2.7 (or $500 \mathrm{mmol} \mathrm{Fe} \mathrm{m}^{-2}$ ) in the topsoil. Organic and inorganic $\mathrm{Fe}+\mathrm{Al}$ also increased with soil $\mathrm{Fe}$. However, inorganic $\mathrm{Fe}+\mathrm{Al}$ only increased when $\log \mathrm{Fe}$ values were 3.0 (or $1000 \mathrm{mmol} \mathrm{Fe} \mathrm{m}^{-2}$ ) or higher. In fact, inorganic $\mathrm{Fe}+\mathrm{Al}$ only substantially increased in the six most Fe-rich Swedish fens, with $\mathrm{Fe}$ contents of at least $4000 \mathrm{mmol} \mathrm{m}^{-2}$. For organic $\mathrm{Fe}+\mathrm{Al}$, which consists of Fe-OM complexes, the 

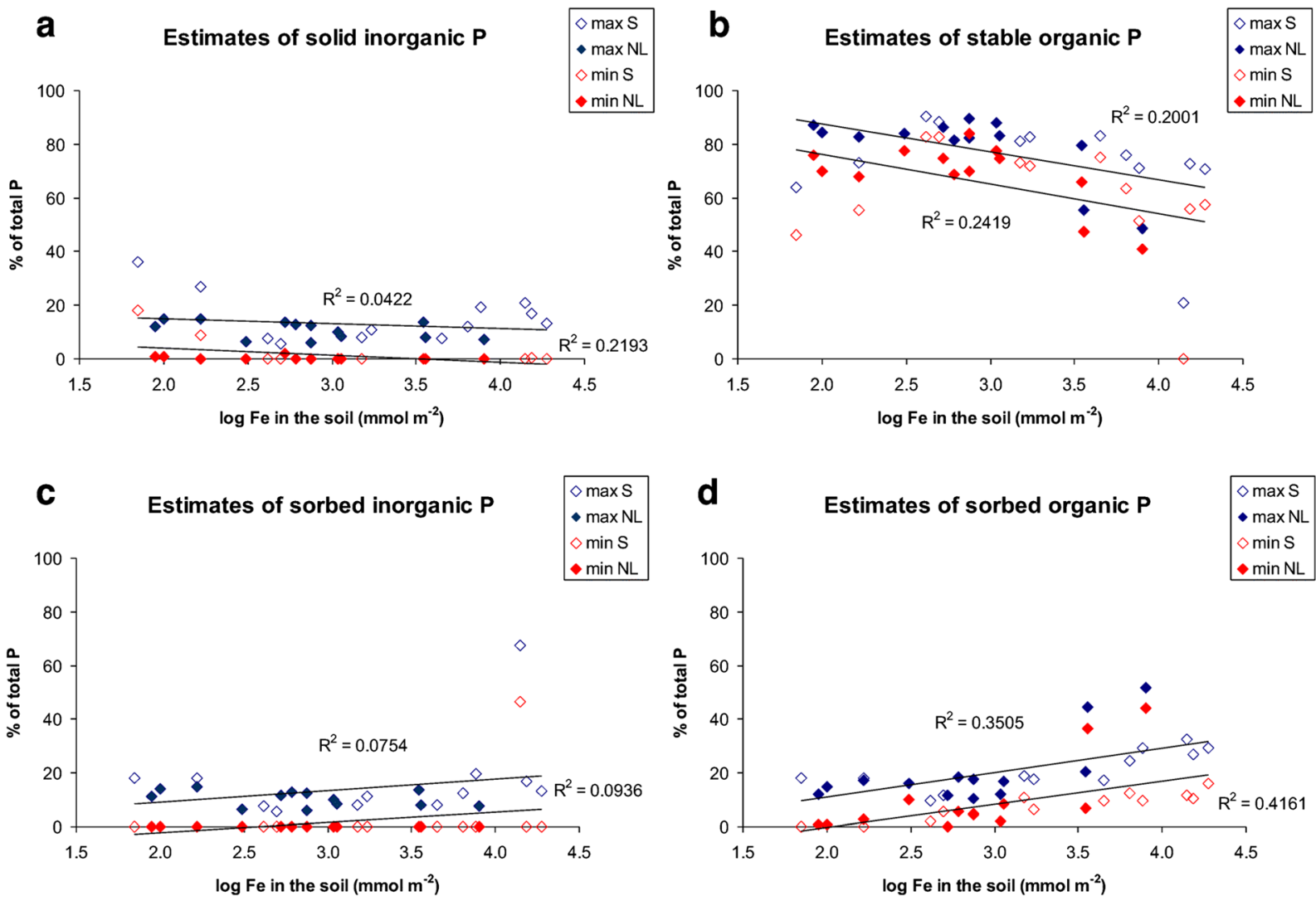

Fig. 5 Minimum and maximum estimates of different forms of inorganic and organic $\mathrm{P}$ in mineral-rich fens in the Netherlands and central Sweden, in relation to $\mathrm{Fe}$ in the soil. $\log \mathrm{Fe}$ is based on the total amounts of $\mathrm{Fe}$ in the upper $10 \mathrm{~cm}$ of the peat soil, expressed in

increase with soil $\mathrm{Fe}$ started much earlier, around $500 \mathrm{mmol} \mathrm{Fe} \mathrm{m}{ }^{-2}$. Also, in most fens, organic $\mathrm{Fe}+$ $\mathrm{Al}$ was higher than inorganic $\mathrm{Fe}+\mathrm{Al}$, even at high soil $\mathrm{Fe}$. Inorganic $\mathrm{Fe}+\mathrm{Al}$ was only substantially higher than organic $\mathrm{Fe}+\mathrm{Al}$ in the six most Fe-rich Swedish fens. This may imply that organic $\mathrm{Fe}+\mathrm{Al}$ was more important to $\mathrm{P}$ sorption and plant $\mathrm{P}$ supply than inorganic $\mathrm{Fe}+\mathrm{Al}$.

The importance of organic $\mathrm{Fe}+\mathrm{Al}$ was further supported by correlations with P-sorption and plant P-supply (Fig. 7). Plant $\mathrm{P}$ content and sorbed $\mathrm{P}$ were highly correlated, and showed $\mathrm{R}^{2}$ values of 0.64 when sorbed $\mathrm{P}$ was expressed as $\log$ value. Sorbed $\mathrm{P}$ also showed high correlations with organic $\mathrm{Fe}+\mathrm{Al}$, but much lower with inorganic $\mathrm{Fe}+$ Al. The latter correlation was not even significant without the log-tranformation of sorbed P. In addition, plant $\mathrm{P}$ content showed a higher correlation with organic than with inorganic $\mathrm{Fe}+\mathrm{Al}$.

mmol m${ }^{-2} . A=$ solid organic $\mathrm{P} ; \mathrm{B}=$ stable organic $\mathrm{P} ; \mathrm{C}=$ sorbed inorganic $\mathrm{P} ; \mathrm{D}=$ sorbed organic $\mathrm{P}$. Correlations were only significant $(\mathrm{p}<0.05)$ for stable organic $\mathrm{P}(\mathrm{B})$ and sorbed organic $\mathrm{P}(\mathrm{D})$

\section{Discussion}

Differences between the Netherlands and Central Sweden

The two regions mainly differed in vegetation characteristics and pore water composition. The fens in central Sweden typically contained plant species with a northern distribution pattern, while Dutch fens contained more temperate species. The higher vascular plant aboveground biomass in the Netherlands may have been due to the longer growing season, as the Dutch fens are located around $52^{\circ}$ instead of $63^{\circ}$ northern latitude. Increased nutrient supply may also play a role, as exchangeable $\mathrm{P}$ and total soil $\mathrm{K}$ were both higher in the Netherlands than in central Sweden. Also, in the Netherlands, atmospheric N-deposition is higher than in central Sweden (Erisman et al. 2015), and higher than the critical loads of $15-17 \mathrm{~kg} \mathrm{ha}^{-1} \mathrm{yr}^{-1}$ for Molinion 


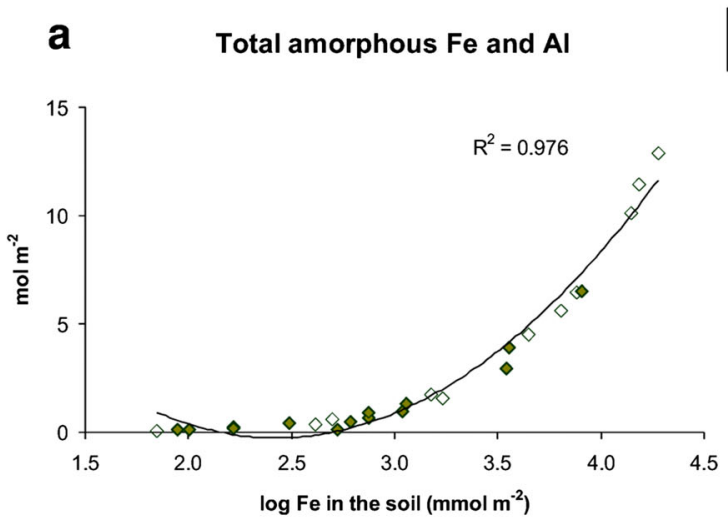

b Total amorphous Fe and Al

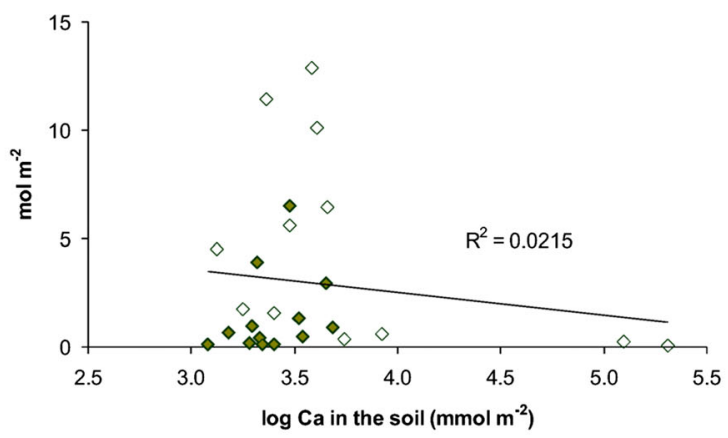

\section{Inorganic amorphous Fe and Al}

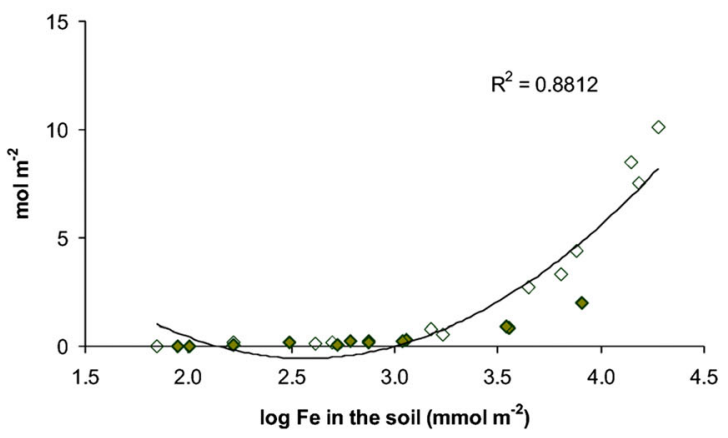

Fig. 6 Total amorphous, inorganic and organic $\mathrm{Fe}$ and in mineralrich fens in the Netherlands and central Sweden in relation to the gradients in $\mathrm{Fe}$ and $\mathrm{Ca}$ in the soil. $\mathrm{Log} \mathrm{Fe}$ and $\log \mathrm{Ca}$ are both based on the total amounts of $\mathrm{Fe}$ and $\mathrm{Ca}$ in the upper $10 \mathrm{~cm}$ of the peat soil, expressed in $\mathrm{mmol} \mathrm{m}{ }^{-2}$. $\mathrm{A}=$ total amorphous $\mathrm{Fe}+\mathrm{Al}$ in

meadows, Alkaline fens or Transition mires (van Dobben and van Hinsberg 2008). Nevertheless, in both regions, the fens mostly belonged to short fens, with low biomass and high species richness, rather than tall fens (Boyer and Wheeler 1989). Plant species richness was high in both the Netherlands and central Sweden, and most plant species were characteristic for mineral-rich fens even under Fe-rich and P-rich conditions, such as the EU-habitat directive species Hamatocaulis vernicosus.

The two regions also differed in pore water chemistry, with higher values for $\mathrm{EC}, \mathrm{Na}, \mathrm{Cl}, \mathrm{SO} 4$ and $\mathrm{DOC}$ in the Netherlands had than in central Sweden. This may reflect the more oceanic location of the Netherlands, and/or pollution of surfacewater from the Rhine river (Cioc 2002). However, these differences in water chemistry did not affect $\mathrm{P}$ availability to any large extent. As already mentioned, only exchangeable $\mathrm{P}$ was higher in the Netherlands than central Sweden, probably due to
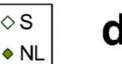

Organic amorphous $\mathrm{Fe}$ and $\mathrm{Al}$

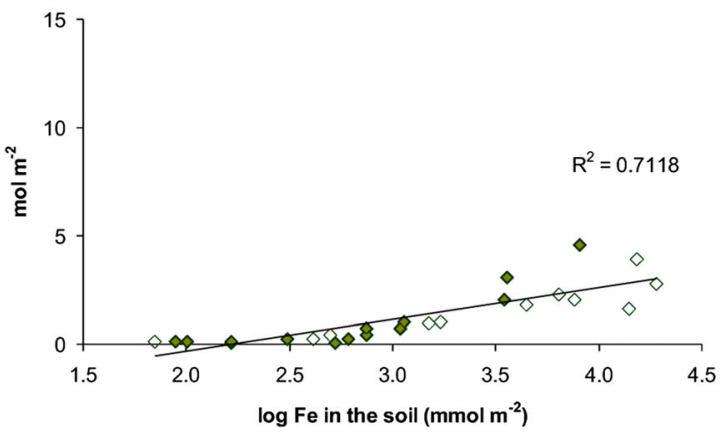

relation to soil $\mathrm{Fe} ; \mathrm{B}=$ total amorphous $\mathrm{Fe}+\mathrm{Al}$ in relation to soil $\mathrm{Ca}$; $\mathrm{C}=$ inorganic $\mathrm{Fe}+\mathrm{Al}$ in relation to soil $\mathrm{Fe} ; \mathrm{D}=$ organic $\mathrm{Fe}+$ $\mathrm{Al}$ in relation to soil Fe. Correlations were significant $(\mathrm{p}<0.05)$ for soil Fe (A,C and D), but not for soil Ca (B)

the generally higher input of $\mathrm{P}$ from agriculture in the surface water, which affects many fens there (e.g., Cusell et al. 2014).

Differences between ca-poor and ca-rich fens

Differences between Ca-poor and Ca-rich fens in vegetation, pore water and soil characteristics were smaller than expected, possibly because the gradient in soil $\mathrm{Ca}$ could only partly be separated from the gradient in soil Fe. However, soil organic matter content was lower in the most extreme Ca-rich fens, due to precipitation of secondary calcium carbonates (Boyer and Wheeler 1989) and the associated dilution effect. Also, these fens were the only ones in which at least part of the inorganic $\mathrm{P}$ consisted of solid forms, which points to coprecipitation of calcium phosphates. The fens with calcite precipitation were also characterized by low $\mathrm{P}$ availability and even P limitation, low herb cover and 

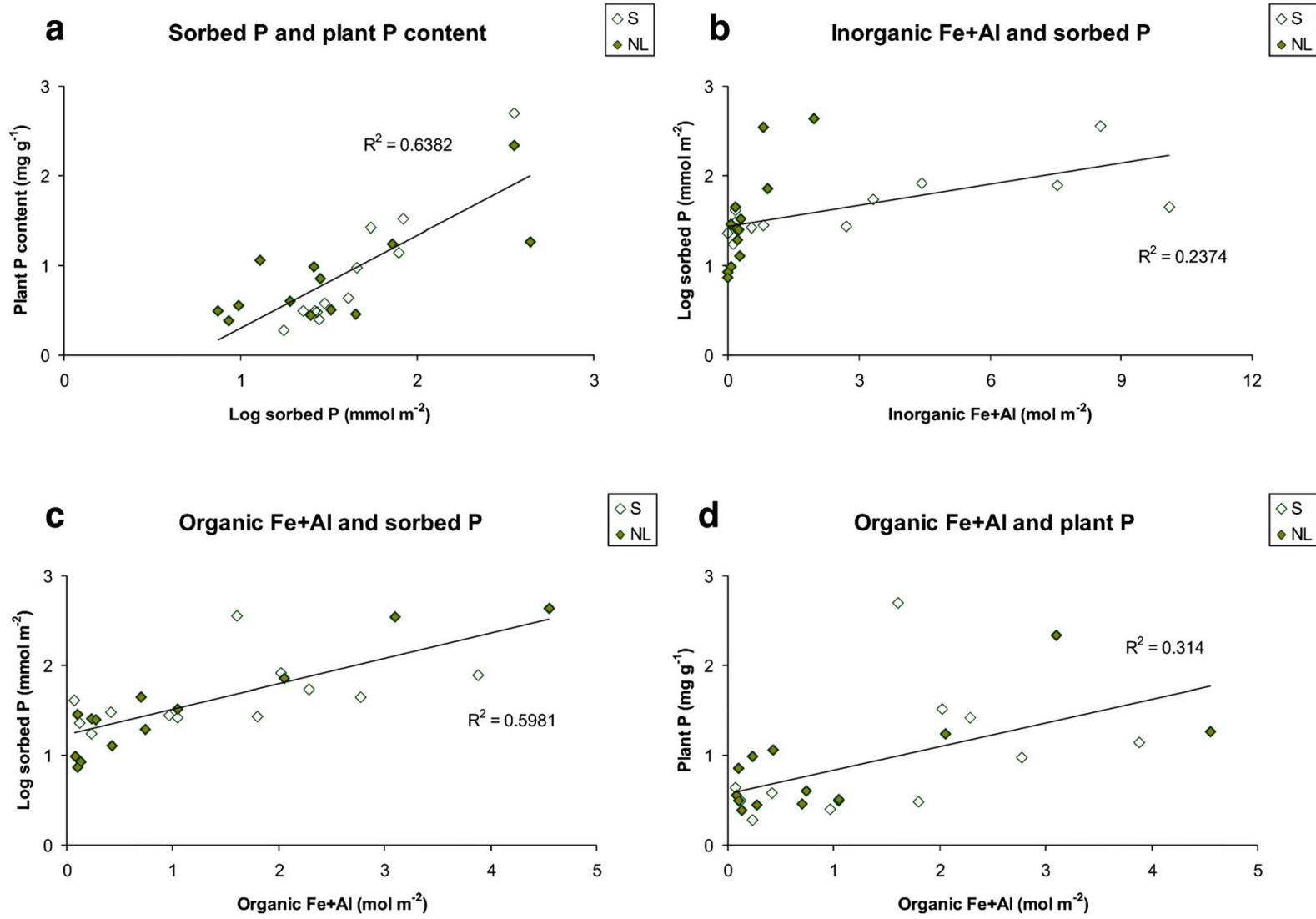

Organic $\mathrm{Fe}+\mathrm{Al}$ and plant $\mathrm{P}$

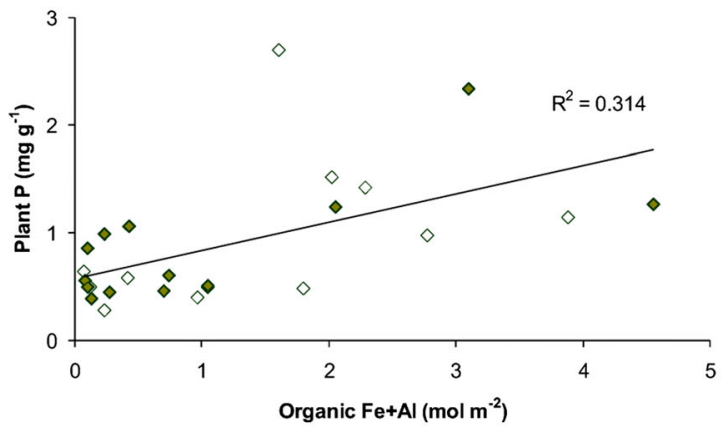

Fig. 7 Relationships between plant and soil characteristics in mineral-rich fens in the Netherlands and central Sweden. A = plant $\mathrm{P}$ content in relation to sorbed $\mathrm{P}$ in the soil; $\mathrm{B}=$ sorbed $\mathrm{P}$ in relation

low number of herb species. However, in many fens, precipitation of calcium phosphate is unlikely, due to undersaturated conditions (Boyer and Wheeler 1989). For many fens with low $\mathrm{P}$ availability, it was more important to be Fe poor than $\mathrm{Ca}$ rich. In Fe-poor fens, $\mathrm{P}$ sorption capacity may be low, because sorption of $\mathrm{P}$ to organic matter is very low (Daly et al. 2001). This suggests, in accord with Emsens et al. (2017), that Fe is more important for $\mathrm{P}$ availability than $\mathrm{Ca}$.

High P-availability in Fe-rich fens

In our study, $\mathrm{P}$ availability to the vegetation clearly increased from Fe-poor to Fe-rich fens. Almost all soil $\mathrm{P}$ fractions increased from $\mathrm{Fe}$-poor to Fe-rich fens, while soil C:P ratios decreased, and vascular plant $\mathrm{P}$ contents more than quadrupled. The decrease in vascular plant $\mathrm{N}: \mathrm{P}$ ratios from 25 to $10 \mathrm{~g} \mathrm{~g}^{-1}$ clearly showed that $\mathrm{Fe}-$ rich fens were not $\mathrm{P}$ limited (Olde Venterink et al. 2003),

to inorganic $\mathrm{Fe}+\mathrm{Al}$ in the soil; $\mathrm{C}=$ sorbed $\mathrm{P}$ in relation to organic $\mathrm{Fe}+\mathrm{Al}$ in the soil; $\mathrm{D}=$ plant $\mathrm{P}$ content in relation to inorganic $\mathrm{Fe}+\mathrm{Al}$ in the soil. All correlations were significant $(\mathrm{p}<0.05)$

but instead characterized by excess P. In the common view, Fe-rich soils have low P availability (Walker and Syers 1976), and high Fe concentrations reduce $P$ loss to overlying surface water or downstream aquatic systems (Zak et al. 2004; Geurts et al. 2008; van der Grift et al. 2016). However, our findings support earlier reports that $\mathrm{P}$ availability within the soil may actually be higher in Fe-rich fens than in Fe-poor fens (Aggenbach et al. 2013; Pawlikowski et al. 2013; Emsens et al. 2017). High Fe levels may thus reduce orthophosphate concentrations in the water, but nevertheless increase $\mathrm{P}$ availability to the vegetation in the peat soil.

Inorganic, organic and sorbed $\mathrm{P}$ in Fe-rich fens

In Fe-rich fens, a large part of the $\mathrm{P}$ flowing in with groundwater and surface water is probably captured by Fe (Emsens et al. 2017), which may explain the higher amounts of total and sorbed $\mathrm{P}$ than in Fe-poor fens. In 
theory, capture of $\mathrm{P}$ by Fe may lead to precipitation of $\mathrm{Fe}$ hydroxyphosphates (van der Grift et al. 2016). However, high amounts of inorganic $\mathrm{P}$ were only found in $\mathrm{Ca}-$ rich fens with calcite precipitation, Also, the presence of stable inorganic P could only be established with some certainty for these Ca-rich fens, which implies that precipitation of iron hydroxyphosphates in Fe-rich fens is less important than expected.

In all fens, a large part of the $\mathrm{P}$ was organic. We did not study the composition of organic $\mathrm{P}$, but in Cheesman et al. (2014), monoesters, which mainly consist of inositol hexakiphosphates (IHP) or phytates, accounted for $62-65 \%$ of organic P in organic wetland soils. Such numbers are found in many soil types (Turner et al. 2007). Phytates are the principal storage form of $P$ in vegetation and seeds, and consist of cyclic acids, saturated with up to six phosphate groups. With so many phosphate groups, phytates are generally more strongly bound to the soil solid phase than labile organic $\mathrm{P}$ (McKercher and Anderson 1989; Gerke 2015). In Carich soils, phytates may even precipitate as Ca3-IHP, which is insoluble at high $\mathrm{pH}$ (Prietzel et al. 2016), and may explain the high proportion of stable organic $\mathrm{P}$ there. In Fe-rich fens, phytates may precipitate with Fe, but especially with Al (Shang et al. 1992).

In most fens, at least part of the organic $\mathrm{P}$ consisted of sorbed organic P. Even though only minimum and maximum estimates could be calculated, sorbed organic P most likely increased from Fe-poor to Fe-rich fens. Sorbed organic P probably mostly consists of labile forms, as phytates are more strongly bound to the soil solid phase (McKercher and Anderson 1989; Gerke 2015). Sorbed organic $P$ is probably an important $P$ source for wetland plants. In terrestrial $\mathrm{Ca}$-rich or $\mathrm{Fe}$ rich habitats, arbuscular mycorrhizal plants predominate, because they efficiently take up inorganic calcium or iron phosphates with their mycorrhizal network (Hoeksema et al. 2010; Smith and Smith 2011). However, in wetland habitats, nonmycorrhizal plants predominate, because mycorrhizal fungi are restricted by low oxygen (Read and Perez-Moreno 2003). Nonmycorrhizal plants have different strategies to take up P, such as root exudation of phosphatase enzymes, which disintegrate organic P (Raven et al. 2018). Such enzymes probably mainly attack labile organic P. For nonmycorrhizal wetland species such as Carex spp., excretion of phosphatase enzymes was almost ten times higher for labile forms of organic $\mathrm{P}$ than for phytate (Güsewell 2017). Also, Carex spp. were able to grow on labile organic P, but not on phytate (Pérez Corona et al. 1996; Güsewell 2017).

Weak P sorption to Fe-OM complexes in Fe-rich fens

In Fe-rich fens, availability of $\mathrm{P}$ to the vegetation probably further increased due to relatively weak P sorption. In fens, $\mathrm{P}$ sorption may be relatively weak, because wet conditions lead to reduction of $\mathrm{Fe}$ (III) to $\mathrm{Fe}(\mathrm{II})$ and lower P-binding capacity (Patrick and Khalid 1974; Emsens et al. 2017). However, as Fe-rich fens also showed high $\mathrm{P}$ availability under drained and oxygenrich conditions (Emsens et al. 2017), this cannot be the only explanation.

In Fe-rich fens, sorption of $\mathrm{P}$ is probably also weak due to the high amount of organic $\mathrm{Fe}+\mathrm{Al}$, which is part of $\mathrm{Fe}-\mathrm{OM}$ complexes. Sorption to $\mathrm{Fe}-\mathrm{OM}$ complexes is weaker than to Fe oxides (Kooijman et al. 2009; Gerke 2010; Gerke 2015). In Fe-OM complexes, organic matter reduces the P-binding capacity, and $\mathrm{P}$ is probably mostly bound in monodentate fashion, with only one phosphate oxygen atom bound to an adjacent Fe surface site rather than two (Kim et al. 2011). Possibly, part of the organic $\mathrm{Fe}+\mathrm{Al}$ consist of fine colloids of iron hydroxide, associated with some OM (Jeanroy and Guillet 1981). However, in soils with high amounts of DOC, such as peat soils, sorption of organic anions to $\mathrm{Fe}$ oxides may be rather high, and transform them into Fe-OM complexes ( $\mathrm{Gu}$ et al. 1994). Also, nonmycorrhizal plants exudate large amounts of carboxylates such as citrate and oxalate, as strategy to improve P uptake (Lambers et al. 2008; Raven et al. 2018). These small organic anions can release organic and inorganic $P$ from the P-sorption complex by ligand exchange (Gerke et al. 2000; Johnson and Loeppert 2006; Gerke 2015), but also weaken future $\mathrm{P}$ sorption by transforming $\mathrm{Fe}$ oxides into Fe-OM complexes (Gu et al. 1994). In any case, organic $\mathrm{Fe}+\mathrm{Al}$ showed higher correlations with sorbed $\mathrm{P}$ and plant $\mathrm{P}$ content than inorganic $\mathrm{Fe}+\mathrm{Al}$. Also, inorganic $\mathrm{Fe}+\mathrm{Al}$ only substantially increased in fens with $\mathrm{Fe}$ content of $4000 \mathrm{mmol} \mathrm{m}^{-2}$ in the topsoil or more, while organic $\mathrm{Fe}+\mathrm{Al}$ already increased at $\mathrm{Fe}$ contents of $500 \mathrm{mmol} \mathrm{m}^{-2}$.

High $\mathrm{P}$ in Fe-rich fens does not lead to high biomass

As already mentioned, high availability of weakly sorbed $\mathrm{P}$ in Fe-rich fens may especially favour nonmycorrhizal wetland plants. Nonmycorrhizal plants 
can mobilize weakly sorbed organic and inorganic P through root exudation of carboxylic anions and ligand exchange (Gerke et al. 2000, Johnson and Loeppert 2006; Gerke 2015), and further increase P-availability through root exudation of phosphatase enzymes, which especially disintegrate labile organic P (Güsewell 2017). Nonmycorrhizal Carex spp. may even produce dauciform roots, especially under P-poor conditions, which excrete large amounts of carboxylic anions such as citrate and oxalate (Bakker et al. 2005; Güsewell 2017). High P-uptake capacity by the vegetation was supported by the clear increase in plant $\mathrm{P}$ content over the gradient from Fe-poor to Fe-rich fens, and the strong correlation with weakly sorbed (organic) P.

However, while high P-availability in Fe-rich fens clearly resulted in higher plant $\mathrm{P}$ uptake, this did not lead to higher aboveground biomass production than in Fe-poor fens. Even in the Netherlands, Fe-rich fens were still mesotrophic and species-rich. Such patterns were also found by Pawlikowski et al. (2013) in pristine fens in Poland, with aboveground biomass around $200 \mathrm{~g} \mathrm{~m}^{-2}$ in both Ca-rich and Fe-rich fens. Emsens et al. (2017) did not report biomass values, but the underlying data revealed that aboveground biomass was $450 \mathrm{~g} \mathrm{~m}^{-2}$ or lower when the two rewetted fens on former agricultural land were excluded, and did not correlate with Fe-content in the soil at all.

Part of the explanation is that Fe-rich fens may be limited by other nutrients than P. In Fe-rich fens, vascular plant $\mathrm{N}: \mathrm{P}$ ratios ranged around $10 \mathrm{~g} \mathrm{~g}^{-1}$, which points to $\mathrm{N}$ as limiting factor (Olde Venterink et al. 2003). Ferich fens may have low $\mathrm{N}$ availability due to high microbial respiration and $\mathrm{N}$ immobilization even under oxygen-poor conditions, with low net $\mathrm{N}$ mineralization as a result (Mettrop et al. 2014). However, in the Netherlands, high atmospheric $\mathrm{N}$ deposition probably reduced $\mathrm{N}$ limitation to some extent.

Aboveground biomass production in Fe-rich fens may also be reduced by Fe-toxicity. In wetland soils, concentrations of reduced Fe may reach high and toxic levels under oxygen-poor conditions (Patrick and Khalid, 1974; Lucassen et al. 2000), although Fe-rich fens are protected to some extent by the high $\mathrm{pH}$ and alkalinity. Also, high Fe tolerance in plant species is associated with low relative growth rates (Snowden and Wheeler 1993).

\section{High P may protect vegetation against Fe-toxicity}

High $\mathrm{P}$ availability in Fe-rich fens may actually protect the vegetation against Fe-toxicity. High $\mathrm{P}$ supply reduced Fe-toxicity in mesocosm experiments of Wheeler et al. (1985), and may lead to iron phosphate precipitation on the roots, although Fe-tolerant species also reduce Fe toxicity with precipitation of iron oxides by radial oxygen loss (Snowden and Wheeler 1995; Fageria 2001). Also, Fe concentrations in the plant clearly decreased with increasing $\mathrm{P}$ concentrations in the nutrient solution (Elliot and Lauchli 1985). High P supply may even lead to Fe deficiency when the latter is in low supply (DeKock and Wallace 1965; Fageria 2001). High $P$ concentrations in the plant may decrease the concentration of active Fe, probably by internal formation of insoluble iron phosphate complexes in the plant cells (Greipsson 1995; Fageria 2001).

Although critical levels for foliar P:Fe ratios have not been established and probably depend on plant species, they indicate to some extent whether plants are affected by Fe deficiency or toxicity. Deficiency of Fe was found for Mustard plants at P:Fe ratios around $140 \mathrm{~g} \mathrm{~g}^{-1}$ (DeKock et al. 1960). In contrast, toxicity of $\mathrm{Fe}$ occurred for Epilobium hirsutum at P:Fe ratios around $0.1 \mathrm{~g} \mathrm{~g}^{-1}$ (Wheeler et al. 1985). In Lucassen et al. (2000), foliar P:Fe ratios for Glyceria fluitans were $0.3-1.8 \mathrm{~g} \mathrm{~g}^{-1}$ in sites with Fe toxicity. In our study, $\mathrm{P}: \mathrm{Fe}$ ratios ranged around $3.3 \mathrm{~g} \mathrm{~g}^{-1}$ in most fens, but between $0.05-0.1$ in two Fe-rich fens, which may thus be close to Fe toxicity. Nevertheless, the plants looked healthy, and diversity was very high. It is however possible that less Fe-tolerant species, or species with less efficient $\mathrm{P}$ uptake do not survive.

\section{Ecological implications}

This study shows that Fe-poor fens are $\mathrm{P}$ limited, due to low Fe concentrations and low amounts of weakly sorbed (organic) $\mathrm{P}$, independent of $\mathrm{Ca}$ richness of the peat soil and potential precipitation of calcium phosphates. This is an advantage, as many characteristic and endangered fen species occur in P limited habitats (Wassen et al. 2005). However, Fe-poor fens are threatened by external $\mathrm{P}$ eutrophication, because high $\mathrm{P}$ availability to the vegetation is not used to combat Fe toxicity, but for increased plant growth. Nevertheless, low Psorption capacity in Fe-poor fens may help to reduce $\mathrm{P}$ availability once the water quality improves. In the Fepoor fens of Kooijman et al. (2016), aboveground biomass decreased from 1000 to $250 \mathrm{~g} \mathrm{~m}^{-2}$ within 25 years, and vascular plant N:P ratios increased from 16 to $23 \mathrm{~g} \mathrm{~g}^{-1}$, which clearly points to lower P availability 
(Olde Venterink et al. 2003). Also, eutrophic bryophytes were replaced by more characteristic species such as Scorpidium scorpioides.

For Fe-rich fens, high $\mathrm{P}$ availability is an inherent characteristic, associated with high amounts of weakly sorbed (organic) P, even in mesotrophic fens with high plant diversity. High $\mathrm{P}$ availability in Fe-rich fens does not necessarily lead to high aboveground biomass production, but may instead protect the vegetation against $\mathrm{Fe}$ toxicity. However, Fe-rich fens are sensitive to other nutrients, such as $\mathrm{N}$ and/or K (Cusell et al. 2014), which may be a problem for fen restoration in former agricultural areas (Emsens et al. 2017). Also, like Fe-poor fens, Fe-rich fens are sensitive to lowered water levels and acidification. However, in undrained situations, Fe-rich fens with high plant diversity and EU-habitat directive species such as Hamatocaulis vernicosus may persist even in the Netherlands, as long as buffer capacity and $\mathrm{pH}$ remain high enough.

Acknowledgements The authors wish to thank Leen de Lange, Bert de Leeuw, and Leo Hoitinga for analytical assistance and Geert Kooijman for assistance in selecting field sites and conducting the fieldwork. Per-Olof Nystrand at the County Administrative Board of Jämtland assisted with obtaining collecting permits (Dnr 522-2464-12) and indicating suitable sampling locations. This research was financially supported by Kennisnetwerk Ontwikkeling en Beheer Natuurkwaliteit $(\mathrm{O}+\mathrm{BN})$ of the Dutch Ministry of Economic Affairs, Agriculture and Innovation.

Open Access This article is distributed under the terms of the Creative Commons Attribution 4.0 International License (http:// creativecommons.org/licenses/by/4.0/), which permits unrestricted use, distribution, and reproduction in any medium, provided you give appropriate credit to the original author(s) and the source, provide a link to the Creative Commons license, and indicate if changes were made.

\section{References}

Aggenbach CJS, Backx H, Emsens WJ, Grootjans AP, Lamers LPM, Smolders AJP, Stuyfzand PJ, Wołejko L, van Diggelen R (2013) Do high iron concentrations in rewetted rich fens hamper restoration? Preslia 85:405-420

Bakker C, Rodenburg J, van Bodegom PM (2005) Effects of caand Fe-rich seepage on $\mathrm{P}$ availability and plant performance in calcareous dune soils. Plant Soil 275:111-121

Bol R, Julich D, Brödlin D, Siemens J, Kaiser K, Dippold MA, Spielvogel S, Zilla T, Mewes D, von Blanckenburg F, Puhlmann H, Holzmann S, Weiler M, Amelung W, Lang F, Kuzyakov Y, Feger KH, Gottselig N, Klumpp E, Missong A, Winkelmann C, Uhlig D, Sohrt J, von Wilpert K, Wu B, Hagedorn F (2016) Dissolved and colloidal phosphorus fluxes in forest ecosystems - an almost blind spot in ecosystem research. J Plant Nutr Soil Sci 79:425-438

Boyer MLH, Wheeler BD (1989) Vegetation patterns in spring-fed calcareous fens: calcite precipitation and constrains on fertility. J Ecol 77:597-609

Cheesman AW, Turner BL, Reddy KR (2014) Forms of organic phosphorus in wetland soils. Biogeosciences 11:6697-6710

Cioc M (2002) The Rhine, an eco-biography 1815-2000. University of Washington Press, Seattle

Cody RP, Smith JK (1987) Applied statistics and the SAS programming language. Elsevier Science Publishers Co, Int 280 pp

Cusell C, Kooijman AM, Lamers LPM (2014) Nitrogen or phosphorus limitation in rich fens? - edaphic differences explain contrasting results in vegetation development after fertilization. Plant Soil 384:153-168

Daly K, Jeffrey D, Tunnet H (2001) The effect of soil type on phosphorus sorption capacity and desorption dynamics in Irish grassland soils. Soil Use Manag 17:12-20

DeKock PC, Wallace A (1965) Excess phosphorus and Iron chlorosis. Calif Agric 19:3-4O

DeKock PC, Hall A, McDonald M (1960) A relation to the ratio between phosphorus to iron and potassium to calcium in mustard leaves. Plant Soil 12:128-142

Emsens WJ, Aggenbach CJS, Smolders AJP, Zak D, van Diggelen R (2017) Restoration of endangered fen communities: the ambiguity of iron-phosphorus binding and phosphorus limitation. J Appl Ecol 54:1755-1764

Erisman JW, Dammers E, van Damme M, Soudzilovskaia N, Schaap M (2015) Trends in EU nitrogen deposition and impacts on ecosystems: an overview of the achievements and the current state of knowledge on reactive nitrogen in Europe, focusing on deposition, critical load exceedances, and modeled and measured trends. Air \& Waste Management Association

European Union (2013) Interpretation manual of European Union habitats, EU-28. European Commission DG Environment

Fageria VD (2001) Nutrient interactions in crop plants. J Plant Nutr 24:1269-1290

Gerke J (2010) Humic (organic matter)-Al(Fe)-phosphate complexes: an underestimated phosphate form in soils and source of plant-available phosphate. Soil Sci 175:417-425

Gerke J (2015) The acquisition of phosphate by higher plants: effect of carboxylate release by the roots. A critical review. J Plant Nutr Soil Sci 178:351-364

Gerke J, Römer W, Beissner L (2000) The quantitative effect of chemical phosphate mobilization by carboxylate anions on $\mathrm{P}$ uptake by a single root. II. The importance of soil and plant parameters for uptake of mobilized P. J Plant Nutr Soil Sci 162:213-219

Geurts JJM, Smolders AJP, Verhoeven JTA, Roelofs JGM, Lamers LPM (2008) Sediment $\mathrm{Fe}: \mathrm{PO}_{4}$ ratio as a diagnostic and prognostic tool for the restoration of macrophyte biodiversity in fen waters. Freshw Biol 53:101-2116

Golterman HL (1996) Fractionation of sediment phosphate with chelating compounds: a simplification, and comparison with other methods. Hydrobiologia 335:87-95

Greipsson S (1995) Effect of iron plaque on roots of rice on growth of plants in excess zinc and accumulation of phosphorus in plants in excess copper or nickel. J Plant Nutr 18:1659-1665 
van der Grift B, Behrens T, Osté LA, Schot PP, Wassen MJ, Griffioen J (2016) Fehydroxyphosphate precipitation and $\mathrm{Fe}(\mathrm{II})$ oxidation kinetics upon aeration of $\mathrm{Fe}(\mathrm{II})$ and phosphate -containing synthetic and natural solutions. Geochimica et Cosmochimica Acte 186:71-90

Gu, B., Schmitt, J., Chen, Z., Llang, L., and McCarthy, J.F. 1994. Adsorption and Desorption of Natural Organic Matter on Iron Oxide: Mechanisms and Models. Environ sci Technol 28:38-48

Güsewell S (2017) Regulation of dauciform root formation and root phosphatase activities of sedges (Carex) by nitrogen and phosphorus. Plant Soil 416:57-72

Hamad ME, Rimmer DL, Syers JK (1992) Effect of iron oxide on phosphate sorption by calcite and calcareous soils. J Soil Sci 43:273-281

Hill MO (1979) TWINSPAN manual ecology and systematics, New York

Hinsinger P (2001) Bioavailability of soil inorganic P in the rhizosphere as affected by root-induced chemical changes: a review. Plant Soil 237:173-195

Hoeksema JD, Chaudhary BV, Gehring CA, Johnson NC, Karst J, Koide RT, Pringle A, Zabinski C, Bever JD, Moore JC, Wilson GWT, Klironomos JN, Umbanhowar J (2010) A meta-analysis of context-dependency in plant response to inoculation with mycorrhizal fungi. Ecol Lett 13:394-407

Jeanroy E, Guillet B (1981) The occurrence of suspended ferruginous particles in pyrophosphate extracts of some soil horizons. Geoderma 26:95-105

Johnson SE, Loeppert RH (2006) Role of organic acids in phosphate mobilization from Iron oxide. Soil Science Society America Journal 70:222-234

Kim J, L W, Philips BL, Grey CP (2011) Phosphate adsorption on the iron oxyhydroxides goethite $(\mathrm{a}-\mathrm{FeOOH})$, akaganeite (b$\mathrm{FeOOH})$, and lepidocrocite (g-FeOOH): a ${ }^{31} \mathrm{P}$ NMR study. Energy Environ Sci 4:4298. https://doi.org/10.1039/c1 ee02093e

Kooijman AM, Paulissen MPCP (2006) Acidification rates in wetlands with different types of nutrient limitation. Appl Veg Sci 9:205-212

Kooijman AM, Dopheide J, Sevink J, Takken I, Verstraten JM (1998) Nutrient limitation and their implications for the effects of atmospheric deposition in lime-poor and lime-rich coastal dunes in the Netherlands. J Ecol 86:511-526

Kooijman AM, Lubbers I, van Til M (2009) Iron-rich dune grasslands: relations between soil organic matter and sorption of Fe and P. Environ Pollut 157:3158-3165

Kooijman AM, Cusell C, Mettrop IS, Lamers LPM (2016) Recovery of rich-fen bryophytes in floating rich fens over the past 25 years by improvement of nutrient status and inundation with base-rich surface water. Appl Veg Sci 19: 53-65

Lambers H, Raven JA, Shaver GR, Smith SE (2008) Plant nutrient-acquisition strategies change with soil age. Trends in Ecology and Evolution 23:95-103

Lamers LPM, van Diggelen JMH, Op den Camp HJM, Visser EJW, Lucassen ECHET, Vile MA, Jetten MSM, Smolders AJP, Roelofs JGM (2012) Microbial transformations of nitrogen, sulfur, and iron dictate vegetation composition in wetlands: a review. Front Microbiol 3:156

Lamers LPM, Vile MA, Grootjans AP, Acreman MC, van Diggelen R, Evans MG, Richardson CJ, Rochefort L,
Kooijman AM, Roelofs JGM, Smolders AJP (2015) Ecological restoration of rich fens in Europe and North America: from trial and error to an evidence-based approach. Biol Rev 90:182-203

Lindsay WL, Moreno EC (1966) Phosphate phase equilibria in soils. Soil Sci Soc Am Proc 24:177-182

Lucassen ECHET, Smolders AJP, Roelofs JGM (2000) Increased groundwater levels cause iron toxicity in Glyceria fluitans. (L) RBr Aquatic Botany 66:321-327

McKeague JA, Bryden JE, Miles NN (1971) Differentiation of forms of extractable iron and aluminum. Soil Sci Soc Am Proc 35:33-38

McKercher RB, Anderson G (1989) Organic phosphate sorption by neutral and basic soils. Commun Soil Sci Plant Anal 20: 723-732

van der Meijden R (2005) Heukels Flora van Nederland, drieëntwintigste druk. Wolters-Noordhoff, Groningen

Mettrop IS, Cusell C, Kooijman AM, Lamers LPM (2014) Nutrient and carbon dynamics in peat from rich fens and sphagnum-fens during different gradations of drought. Soil Biol Biochem 68:317-328

Mettrop IS, Neijmeijer T, Cusell C, Lamers LPM, Hedenäs L, Kooijman AM (2018) Calcium and iron as important drivers of brown moss composition through differential effects on Pavailability. J Bryol 40:350-357

Olde Venterink H, Wassen MJ, Verkroost AWM, de Ruiter PC (2003) Species richness-productivity patterns differ between N-, P-, and K-limited wetlands. Ecology 84:2191-2199

Patrick WH, Khalid RA (1974) Phosphate release and sorption by soils and sediments: effect of aerobic and anaerobic conditions. Science 186:53-55

Pawlikowski P, Abramczyk K, Szczepaniuk A (2013) Nitrogen: phosphorus ratio as the main ecological determinant of the differences in the species composition of brown-moss rich fens in North-Eastern Poland. Preslia 85:349-367

Pérez Corona ME, van der Klundert I, Verhoeven JTA (1996) Availability of organic and inorganic phosphorus compounds as phosphorus sources for Carex species. The New Phytologist 133:225-231

Prietzel J, Klysubun W, Werner F (2016) Speciation of phosphorus in temperate zone forest soils as assessed by combined wetchemical fractionation and XANES spectroscopy. J Plant Nutr Soil Sci 179:168-185

Raven, J.A., Lambers, H., Smith, S.E., \& Westoby, M. 2018. Costs of acquiring phosphorus by vascular land plants: patterns and implications for plant coexistence. New Phytol 217:14201427

Read DJ, Perez-Moreno J (2003) Mycorrhizas and nutrient cycling in ecosystems - a journey towards relevance. New Phytol $157: 475-492$

Schwertmann U (1964) Differenzierung der eisenoxide des bodens durch extraktion mit ammoniumoxalat-lösung. Zeitschrift für Pflanzenernährung Düngung und Bodenkunde 105:194-202

Shang C, Stewart JWB, Huang PM (1992) pH effect on kinetics of adsorption of organic and inorganic phosphates by shortrange ordered aluminum and iron precipitates. Geoderma 53:1-14

Smith SE, Smith FA (2011) Roles of arbuscular mycorrhizas in plant nutrition and growth: new paradigms from cellular to 
ecosystem scales. Annual Reviews in Plant Biology 62:227250

Snowden RED, Wheeler BD (1993) Iron toxicity to fen plant species. J Ecol 81:35-46

Snowden RED, Wheeler BD (1995) Chemical changes in selected wetland plant species with increasing Fe supply, with specific reference to root precipitates and Fe tolerance. New Phytol 131:503-520

Thistleton J, Clark T, Pearce P, Parsons SA (2001) Mechanisms of chemical phosphorus removal 1-Iron (II) salts. Trans IChemE 79 Part B

Turner BL, Condron LM, Richardson SJ, Peltzer DA, Allison VJ (2007) Soil organic phosphorus transformations during pedogenesis. Ecosystems 10:1166-1181

Van Dobben HF, van Hinsberg A (2008) Overzicht van kritische depositiewaarden voor stikstof, toegepast op habitattypen en Natura 2000-gebieden. Alterra-rapport 1654. Alterra, Wageningen, p 78

Van Tooren BF, Sparrius LB (2007) Voorlopige verspreidingsatlas van de Nederlandse mossen. Bryologische en Lichenologische werkgroep van de KNNV, vol 350, Zeist, the Netherlands

Verhoeven JTA, Maltby E, Schmitz MB (1990) Nitrogen and phosphorus mineralization in fens and bogs. J Ecol 78:713726

Walker TW, Syers JK (1976) The fate of phosphorus during pedogenesis. Geoderma 15:1-19
Wassen MJ, Olde Venterink H, Lapshina ED, Tanneberger F (2005) Endangered plants persist under phosphorus limitation. Nature 437:547-550

Westerman RL (1990) Soil testing and plant analysis, Third edn. Soil Science Society of America, Madison, Wisconsin

Wheeler BD, Al Farraj MM, Cook RED (1985) Iron toxicity to plants in base-rich wetlands: comparative effects on the distribution and growth of Epilobium hirsutum L. and Juncus subnodulosus Schrank. New Phytol 100:653-669

Zak D, Gelbrecht J, Steinberg CEW (2004) Phosphorus retention at the redox interface of peatlands adjacent to surface waters in Northeast Germany. Biogeochemistry 70:357-368

Zak D, Gelbrecht J, Wagner C, Steinberg CEW (2008) Evaluation of phosphorus mobilization potential in rewetted fens by an improved sequential chemical extraction procedure. Eur J Soil Sci 59:1191-1201

Zou Y, Zhang L, Wang L, Zhang S, Yu X (2018) Effects of aeration, vegetation, and iron input on total $\mathrm{P}$ removal in a lacustrine wetland receiving agricultural drainage. Water 10 : 61. https://doi.org/10.3390/w10010061

Publisher's note Springer Nature remains neutral with regard to jurisdictional claims in published maps and institutional affiliations. 